\title{
A Transformational Melancholy: One Law Professor's Journey Through Depression
}

Marjorie A. Silver

Touro Law Center, msilver@tourolaw.edu

Follow this and additional works at: https://digitalcommons.tourolaw.edu/scholarlyworks

Part of the Legal Education Commons, and the Psychiatric and Mental Health Commons

\section{Recommended Citation}

Silver, Marjorie A., "A Transformational Melancholy: One Law Professor's Journey Through Depression" (2011). Scholarly Works. 621.

https://digitalcommons.tourolaw.edu/scholarlyworks/621

This Article is brought to you for free and open access by the Faculty Scholarship at Digital Commons @ Touro Law Center. It has been accepted for inclusion in Scholarly Works by an authorized administrator of Digital Commons @ Touro Law Center. For more information, please contact Iross@tourolaw.edu. 


\title{
A Transformational Melancholy: One Law Professor's Journey Through Depression
}

\author{
Marjorie A. Silver*
}

\section{Introduction}

In the fall 2007 issue of the Journal of Legal Education, Professor James Jones shared his deeply personal, remarkable, ongoing, story of living, struggling and succeeding as a law professor with bipolar disorder. ${ }^{1}$ His essay ended with an invitation to other members of the legal academy to contact him or Professor Elyn Saks, author of the extraordinary memoir, The Center Cannot Hold, ${ }^{2}$ if interested in forming a confidential support group for legal academics with mental illness. This is my public response to Professor Jones' invitation.

I, too, have struggled with a mental disorder. Luckily, however, unlike that of Professor James Jones or Elyn Saks, my story is one of episodic, not chronic, mental illness. Over the course of more than three decades, I have suffered six episodes of major clinical depression. However, I have been blessed with a combination of compassionate, loving people, wise professionals, a fair amount of good luck, and a basically optimistic and resilient personality. ${ }^{3}$ With the consistent support of family,

\footnotetext{
* Professor of Law, Touro Law Center. My gratitude to my wonderful research assistants, Alyson BermanLonardo, Brittany Fiorenza, Lisa Carbucci, Mark Guarriello and Katharine O’Dette. I especially want to acknowledge Katharine O'Dette for her outstanding research and writing that contributed to the section on What We Know About Depression. Karen Arenson, Lucy Block, Louise Harmon, Jonathan Silver and David Wexler gave me valuable and diverse feedback on drafts at various stages. Thanks, too, to the outstanding professional librarian staff at the Touro Law Library. More than one Touro Law Center faculty summer research grant has helped fund this work; for that, too, I am most grateful. In order not to disserve the people in my life, now and before, I want to claim responsibility for the vagaries of memory and the subjectivity of experience. I take responsibility for any errors, factual or otherwise.

${ }^{1}$ James T.R. Jones, Walking the Tightrope of Bipolar Disorder: The Secret Life of a Law Professor, $57 \mathrm{~J}$. LEGAL ED. 349 (2007).

${ }^{2}$ See Elyn R. SAKS, The Center CANnot Hold (2007). See also James T.R. Jones, Surviving the Scourge of Schizophrenia: A Law Professor's Story: A Review of Elyn Saks' THE CENTER CANNOT Hold: My JouRnEY THROUGH MADNESS, 19HASTINGS WOMEN'S L. J. 105 (2008) (book review).

${ }^{3}$ See Helen Achat, Ichiro Kawachi, et al., Optimism and Depression as Predictors of Physical and Mental Health Functioning: The Normative Aging Study, abstract available at http://www.springerlink.com/content/e2144256342w2111/fulltext.pdf?page=1 (last visited Feb. 18, 2010) (The abstract, in introducing this study, explains that a growing body of evidence shows that optimistic patients tend to have better health-related and psychological outcomes than those who are not optimistic. Specifically, optimistic people tend to have "faster rates of postoperative recovery following cardiac bypass
} 
friends, empathetic employers, and caring psychiatrists, I have, despite it all, thrived. To paraphrase Martin Luther King, Jr., the arc of my life has been long, but it has bent towards health. ${ }^{4}$

I share my story here for several reasons. One is to join Professors Jones' and Saks' brave campaigns to help de-stigmatize, to normalize, mental illness generally, and among the legal academy in particular. ${ }^{5}$ Another is my supposition that there are more law professors who have suffered from clinical depression similar to what I have experienced than have coped with either schizophrenia or bipolar disorder. Finally, I hope to inspire others who have borne mental illness to use their own experiences, when feasible, ${ }^{6}$ to help their students, colleagues, and the practicing bar.

I am a sixty-three year old female law professor with two children, two grandchildren, a husband, and a personal and professional life that I love. I celebrate twenty-eight years of law teaching this year, more than thirty-six years since my first episode of clinical depression, and less than five years since my most recent one. When not depressed-which is, happily, the great majority of the time-I have an abundance of joy and wellbeing in my life. While I have suffered greatly during episodes, depression has not kept me from having a wonderful life. And, in recent years, it has played a role in shaping an important component of my professional calling.

surgery" and a lower likelihood "to be rehospitalized for secondary events [six] months later," "higher psychological well-being in groups at risk of mental disorders," and more "positive outcomes among cancer survivors." Further, optimistic patients tend to take on more positive health practices, which may lead to prevent of chronic diseases.); Optimism and Perceived Competence: Important Resilience Resources, Psychology Today, available at http://www.psychologytoday.com/blog/dont-delay/200903/optimism-and-perceived-competenceimportant-resilience-resources (2009) (last visited Feb. 18, 2010) (describing one study's results, this article explains that healthy outcomes were related to optimism.).

${ }^{4}$ See Rev. Martin Luther King, Jr., Speech, Where Do We Go From Here, Address to the Southern Christian Leadership Conference in Atlanta, Georgia (Aug. 16, 1967) (transcript available at http://www.writespirit.net/inspirational_talks/political/martin_luther_king_talks/where_do_we_go_from_h ere/view) and http://www.wealthandwant.com/docs/King_Where.htm) ("[T]he arc of the moral universe is long but it bends toward justice.").

${ }^{5}$ I have enormous respect and admiration for James and Elyn on writing openly about something so stigmatized, personal, and difficult to reveal.

${ }^{6}$ By feasible, I mean when doing so would be consistent with healthy life choices. Elyn Saks, James Jones and I have all achieved tenure and are settled in our careers. It might well be psychologically and professionally risky for an individual pre-tenure to take a public stance. On the other hand, as more of us "come out of the closet," hopefully the risk will diminish. 


\section{What We Know About Depression}

All of us have experienced moments of depression at various junctures in our lives, just as we have experienced happiness, frustration, anger, and a whole cadre of other emotions. Clinical depression, however, is not just a fleeting feeling or a temporary mood response to an unsatisfactory event. It is a serious mental and physical illness. ${ }^{7}$ A clinical diagnosis of depression results from a depressed mood or a lack of interest in one's regular activities that endures for at least two weeks, and is accompanied by at least four of the following symptoms: change in weight or appetite, lack of sleep, excessive sleeping, lethargy or restlessness, lack of energy, difficulty with concentration and decision-making, feelings of worthlessness or guilt, and contemplation of death or suicide. ${ }^{8}$ It is often paired, as in my case, with intense anxiety. ${ }^{9}$ In its more severe form, such as that which I have experienced, major clinical depression seriously compromises one's ability to participate in the world, and is often accompanied by severe cognitive distortions. ${ }^{10}$

Depression affects $20 \%$ of the population in the United States and worldwide. ${ }^{11}$ Approximately 14.8 million American adults (6.7\% of the U.S. population) are affected by major depression in a given year. ${ }^{12}$ Lawyers experience depression at least twice the frequency as the general population. ${ }^{13}$ While there are numerous speculations on the reasons for these high levels of depression among lawyers, ${ }^{14}$ substantial evidence exists that law school is a significant contributing factor. ${ }^{15}$

\footnotetext{
${ }^{7}$ PATRICIA Ainsworth, UNDERSTANDING DEPRESSION x (2000).

${ }^{8}$ DOn CARroll, A LaWYer's Guide to HEALING 69-70 (2006). [Refer to DSM?]

${ }^{9}$ [need cite].

${ }^{10}$ [need cite].

${ }^{11}$ AINSWORTH, supra note [] at $\mathrm{x}$.

${ }^{12}$ Kessler R.C., Chiu W.T., Demler O., Walters E.E. Prevalence, severity, and comorbidity of twelvemonth DSM-IV disorders in the National Comorbidity Survey Replication (NCS-R). Archives of General Psychiatry, 2005 Jun; 62(6):617-27; U.S. Census Bureau Population Estimates by Demographic Characteristics. Table 2: Annual Estimates of the Population by Selected Age Groups and Sex for the United States: April 1, 2000 to July 1, 2004 (NC-EST2004-02) Source: Population Division, U.S. Census Bureau Release Date: June 9, 2005. http://www.census.gov/popest/national/asrh/.

${ }^{13}$ J. Kim WRIGHT, LAWYERS AS PEACEMAKERS 138 (2010).

${ }^{14}$ Joan E. Mounteer, Depression Among Lawyers, 33 Colo. LAW. 35, 36 (2004). [Add more sources here]

${ }^{15}$ Amiram Elwork, Ph.D., Stress Management FOR Lawyers 15 (2007). [Add cites to Krieger \&
} Sheldon] A study conducted at the School of Law at the University of Arizona found that law students 
Women are more prone to depression than men. ${ }^{16}$ Among lawyers in particular, females report higher levels of stress, anger, and overall psychological distress than male lawyers. ${ }^{17}$ Women are also susceptible to a depression that arises from their unique role as bearers of children: postpartum depression. ${ }^{18}$ Nearly 400,000 women in the United States experience postpartum depression each year. ${ }^{19}$ Eight out of ten women will experience an alteration in their mood during or after the pregnancy. ${ }^{20}$ For most women, feelings of the "baby blues" will resolve within two weeks. ${ }^{21}$ Clinical postpartum depression, however, like clinical depression generally, may last much longer, ${ }^{22}$ and may seriously impair a woman's ability to care for her child. ${ }^{23}$ As with other manifestations of clinical depression, it may involve irrational fears of incompetence, intense anxiety, regrets over giving birth to the child, and thoughts of

began to diverge from their non-law student counterparts by the spring semester, exhibiting high rates of depression, anxiety, hostility, and paranoia. Id. [KOD: Who did this study? What year?]

${ }^{16}$ Kessler R.C., Berglund P., Demler O., Jin R., Koretz D., Merikangas K.R., Rush A.J., Walters E.E., Wang P.S. The epidemiology of major depressive disorder: results from the National Comorbidity Survey Replication (NCS-R). Journal Of THE AMERICAN MEDICAL AsSOCIATION, 2003; Jun 18; 289(23):3095105.

${ }^{17}$ Connie J. A. Beck, Bruce D. Sales, \& Andrew H. Benjamin, Lawyer Distress: Alcohol-Related Problems and Other Psychological Concerns Among a Sample of Practicing Lawyers, 10 J.L. \& HeALTH 1, 3 (1995). However, there is a debate in the literature whether this result is due to women being more inclined to recognize such distress and to feel comfortable reporting it or that women are actually more vulnerable to psychological distress. Id. at 58; Ronald C. Kessler et al., Sex Differences in Psychiatric Help-Seeking: Evidence from Four Large Scale Surveys, 22(1) J.oF HEALTH \& SOC. BEHAV. 49, 60 (1981) (stating, "Women are more ready than men to translate nonspecific feelings of psychiatric symptoms into conscious problem recognition."); But see Susan Nolen-Hoeksema, Sex Differences in Unipolar Depression: Evidence and Theory, 101(2) PSYCH. BULL. 259, 266 (1987) (stating, "The hypothesis that the lower rates of depression observed in men are due to men's unwillingness to admit to their depressive symptoms has not been consistently supported. Men appear to be just as likely to admit to and seek help for a given level of depression."). Elwork attributes these gender differences to society's additional expectations of women as homemakers and the primary caretakers of their children. Id. at 37. In addition to juggling multiple roles, women have also been found to be more prone then men to focus on "humanistic values, to care about the general well-being of all parties involved, and to strive for cooperation, harmony, and civility in the practice of law." Id. at 37-38. This focus on ethical considerations clash with many of the established traditions of the legal profession and can often create added stress to those who focus on these issues as opposed to those who overlook them. Id.

${ }^{18}$ AmErican Psychiatric Ass'n, Diagnostic and Statistical Manual of Mental Disorders (4th ed. Text rev.2000).

${ }^{19}$ Ronald Rosenberg, et al., Conguering PostPartum Depression: A Proven Plan For Recovery xviii (2003).

${ }^{20} \mathrm{Id}$.

${ }^{21} I d$. at 8.

${ }^{22} I d$.

${ }^{23}$ See Id. at 8-9. 
death or suicide. ${ }^{24}$ Previous episodes of clinical depression are risk factors for postpartum depression. ${ }^{25}$

Both psychotherapy and medication have been proven effective in resolving depression. ${ }^{26}$ However, those who have experienced more than one episode have a greatly increased risk of experiencing additional episodes. ${ }^{27}$ And while depression will almost always eventually pass, ${ }^{28}$ each additional episode shortens life expectancy, ${ }^{29}$ and threatens to seriously compromise the individual's relationships and occupations. ${ }^{30}$

\section{My journey through six plus decades (much abridged)}

I was a rather nervous, high strung child, extremely homesick at camp, and, while I always excelled at school, as a young child I had tremendous difficulty separating from my mother and returning to school each fall. I suffered from stomach ailments and, as I got older, frequent headaches. However, in the Long Island suburban Jewish

${ }^{24} I d$. at $6,8$.

${ }^{25}$ Cheryl Tatano Beck \& Jeanne Driscoll, PostPartum MOOD AND ANXIETy Disorders: A CLINICIAN'S GUIDE 61 (2006).

${ }^{26}$ See, e.g., Nat'l Inst. of Mental Health,

http://www.csus.edu/indiv/b/brocks/Courses/.../NIMH\%20Depression.pdf (last visited Aug. 19, 2011): Most do best with combined treatment: medication to gain relatively quick symptom relief and Psychotherapy to learn more effective ways to deal with life's problems, including depression. Depending on the patient's diagnosis and severity of symptoms, the therapist may prescribe medication and/or one of the several forms of psychotherapy that have proven effective for depression.

${ }^{27}$ See, e.g. Patient Information About Antidepressant Medication, Blue Cross Blue Shield of Georgia website, http://www.bcbsga.com/provider/noapplication/plansbenefits/diseasemgmt/notertiary/pw_ad050077.pdf (last visited Feb. 6, 2010).

If a person suffers one major depressive episode, he or she has a 50\% chance of a second episode. If the individual suffers two major depressive episodes, the chance of a third episode is $75 \%-80 \%$. If the person suffers three episodes, the likelihood of a fourth episode is $90 \%-95 \%$

See also Bradley N. Gaynes, MD, MPH and Gerald Gartlehner, MD, MPH, Commentary on the American College of Physicians' Clinical Practice Guidelines for Using Second-Generation Antidepressants to Treat Depressive Disorders, National Guideline Clearinghouse, Rockville (MD), available at http://www.guideline.gov/expert/commentary.aspx?file=ACP_Antidepressants.inc (posted September 2009) (last visited Feb. 6, 2010) (The National Guidelines Clearinghouse is an initiative of the Agency for Healthcare Research and Quality, U.S. Department of Health and Human Services, and it provides summaries of evidence-based clinical practice guidelines and related documents. Patients with two prior episodes of depression have about a 75\% chance of having a third depressive episode, and those with three or more depressive episodes have a greater than $90 \%$ chance of having another depressive episode.")

${ }^{28}$ Except of course in those instances where the individual attempts suicide and succeeds. [cite needed for proposition in text].

${ }^{29}$ [cites needed]

${ }^{30}$ [cites needed] 
family in which I was raised, my parents never thought to consult a mental health professional on my behalf. ${ }^{31}$ Anxiety was a regular part of my life, but I never suffered any kind of "break down." ${ }^{32}$ That is, not until after my son Joshua was born in 1975. My first husband, J, was my high school sweetheart. ${ }^{33} \mathrm{~J}$ was a year ahead of me. We married in 1969, immediately after he graduated from Yale College, following my third year at Brandeis University; ${ }^{34}$ we went to Penn Law School together after I graduated. We both thrived at Penn, and were fortunate to obtain wonderful clerkships in the same federal courthouse in Philadelphia from 1973 to 1974. Thereafter we moved to New York where I started work in the Regional Attorney's office of the then federal Department of Health, Education and Welfare. Our son, Josh, was born less than a year later.

\footnotetext{
${ }^{31}$ This, despite the fact that my father's lifelong best friend was Bill Console, a well-respected psychiatrist. See infra note [] (discussing Bill Console).

${ }^{32}$ In THE NOONDAY DEMON (2001), Andrew Solomon looks for inklings in his earlier life that might have foreshadowed the major breakdown he had in his thirties, after his mother died. Id. at 40-43. I, too, can identify such foreshadowings: intense homesickness at sleep away camp at ages 8 and 11; frequent headaches and generalized anxiety during law school and my subsequent clerkship, for which one physician recommended (1) Inderal ${ }^{\mathrm{TM}}$ (Propranolol) and (2) that I get pregnant. See Nancy Mairs, On Living Behind Bars 181, 189 in UnHOly GHOST: WRITERS ON DEPRESSION (NELl CASEY, ed. 2002). Mairs received similar advice.] I bristled at the latter advice, but unquestioningly took the former. I fainted after my first dosage of Inderal, and immediately ceased taking it. Why he prescribed Inderal, especially if he was advising me to get pregnant, I don't know, and have often wondered. See Worried Sick, 22 Consumer REPORTS ON HEALTH 9 (February 2010) ("Beta-blockers such as propranolol (Inderal and generic) can ease physical symptoms, such as palpitations, sweating, or trembling hands, that accompany some anxiety disorders.... But they don't ease anxiety itself.")

Unlike Solomon, who describes his parents as loving and devoted, both to each other and to their two sons, SOLOMON at 39-40, my parents had what I must acknowledge was a rather toxic marriage. I had an adoring, loving, albeit chronically anxious, mother and a very difficult, emotionally distant and nonengaged father. However, neither Solomon nor I experienced any early major trauma, abandonment or abuse that might explain the intensity of our later breakdowns. See, in contrast, Lesley Dorman's account of her sexual relationship with her stepfather, in Planet No, 229, in CASEY at 232, and her speculation of its connection to her depression. Id. at 239.

${ }^{33}$ Looking back, I think in many ways, J replaced my mother as my comfort person, my anchor. The world was too scary to venture out into alone, so I went to college with an invisible chain around my neck which said to other boys "Keep Away. I belong to J." I missed out on a lot, but I didn't realize that until years later.

${ }^{34}$ While reading Lesley Dorman, Planet No 229, in CASEY, supra note [32], I was reminded of something (likely) relevant from my time at Brandeis: two of the extra-curricular activities in which I engaged involved mental hospitals. I ran a French discussion group for teenagers at the well-known private Mclean Hospital in nearby Belmont, and did volunteer work with children with Down's syndrome in the state mental hospital in Waltham (which was probably Metropolitan State Hospital, see Nancy Mairs, On Living Behind Bars 181, 182 in CASEY, supra note [32]. Dorman discusses how, long before she ever realized that she suffered from depression, she "was drawn to Silver Hill because it was a mental hospital. But what would mental illness have to do with me?" See Dorman, at 233.
} 
I had a wonderful pregnancy and an easy delivery, and experienced a sense of euphoria for the first two weeks of Josh's life. ${ }^{35}$ Then everything changed. Over the course of the next several weeks, I developed extreme, debilitating anxiety, couldn't sleep, and had no appetite. ${ }^{36}$ I finally consulted a psychiatrist, Dr. L, recommended by my father's boyhood friend, William Console, who himself was a psychiatrist. ${ }^{37}$

On May $27^{\text {th }}$, I met with Dr. L, who immediately prescribed antidepressant medication. I started on Elavil ${ }^{\mathrm{TM}}$ on May $28^{\text {th }}$. At that time, however, little was known about effective dosage of such drugs, and it is unclear how much that drug helped; as I shall describe, I cycled in and out of deep depression for several months.

I saw Dr. L daily for the first several days. According to my notes, I was very "zombie-like," a state in which I felt completely emotionally numb. On Dr. L's suggestion, J, Josh and I went to my parents' house for the weekend. I began to feel euphoric on the drive out to Long Island, and stayed that way all day. Over the next week or so, I went slowly down, then slowly up again. This pattern continued to repeat itself, with the "up" and "down" periods of varying lengths. ${ }^{38}$ Although the reasons are now lost to me, according to my notes, I began to phase off Elavil during the second half of June, during an extended "up" period, but when, on June $28^{\text {th }}$, our car broke during a road trip, down I went as well, and resumed taking Elavil again within days of having phased off completely. ${ }^{39}$

One of the external sources of my intense anxiety was an impending move to the Washington D.C. area, as J had been hired as special assistant to a Columbia law professor who had recently accepted an appointment in the new Carter administration

\footnotetext{
${ }^{35}$ I recently uncovered a photocopy of a handwritten chronology I wrote that starts with Josh's birth on April 4, 1975, and goes through September 29, 1975. Some of the details that follow are taken from that chronology.

${ }^{36}$ I grew increasingly upset with Josh's crying and gas between April $18^{\text {th }}$ and May $20^{\text {th }}$. From May $20^{\text {th }}$ to $24^{\text {th }}$, during a house hunting trip in Washington, D.C., see infra text at note [], I became extremely anxious and suffered sleepless nights.

${ }^{37}$ I saw Dr. Console on May $25^{\text {th }}$. By then I was extremely depressed. Sometime thereafter, he told my father that he wasn't surprised. See supra note [31]. What did he mean? Was it because of the nervous child I had been? Because of my mother's low-grade, yet chronic, anxiety and depression? My parents' dysfunctional marriage? I have deep regret that he died before I was ever able to ask him why he said that. ${ }^{38}$ See infra text at notes [].

${ }^{39}$ For discussion of appropriate length of treatment with antidepressants, see infra note [112].
} 
as General Counsel to a new federal agency. On the advice of others, we considered buying a house in the D.C. area, rather than renting. I found this undertaking to be overwhelmingly anxiety-provoking. Ultimately, we abandoned plans to buy, and J, on his own, found us a house to rent in Bethesda, Maryland. While I remained on Long Island with my parents and baby, J moved us out of our Greenwich Village apartment and down to Maryland. ${ }^{40}$ Dr. L found me a psychiatrist in Chevy Chase, Maryland, Dr. Z, whom I began to see about twice a week.

When I started to write this memoir of my depressions, I realized that manymost, in fact - of the details were rather fuzzy (how did Elyn Saks recollect her life and illness so well?!? ${ }^{41}$ ) So I did some "research," by attempting to gather all of the journals, written thoughts, logs of medication, recalled dreams committed to paper-any writings that I could find relating to the times in which I experienced my bouts of depression. ${ }^{42}$ The most powerful and poignant document is a diary I began writing on July 12, 1975 and ended on December 14 of that year. It captures far better than my memories what that first episode of depression was like. ${ }^{43}$

\footnotetext{
${ }^{40} \mathrm{~J}$ rented the house in the second week of June, and moved us out of our apartment on July $2^{\text {nd }} . \mathrm{J}$ went down to Bethesda on July $3^{\text {rd }}$ to meet the movers. Josh and I stayed with my parents throughout the move. We flew down to join J on July $5^{\text {th }}$. I was "down" for this entire period, and stayed that way until my parents' visit on July $12^{\text {th }}$.

${ }^{41}$ SAKS, generally, supra note [].

${ }^{42}$ In fact, I gathered all of my journals and diaries that I could find, going back as far as my childhood, although I have yet to find the time to read them all.

${ }^{43}$ Although originally handwritten, I carefully typed that diary and, in fact, attempted in December, 1975, unsuccessfully, to have it published. Just recently, I uncovered a handwritten letter from Dr. L, dated January 24, [1976], to whom I had also apparently sent my manuscript:

Dear Mrs. Silver,

It was good to hear from you and to share your experiences through your diary. After reading it, I found myself wondering whether, after December 14-in the period of time before I received the diary (mid-January) you had found some peace and stability. What came through so clearly-[] your desperation and fear-was a kind of restlessness, swift changes of mood. What concerns me about that shifting of feeling is the emotional climate in which you were forced to live-one in which, as you are possibly aware-is not helpful in making important decisions. Frankly, I hope your life has settled down, so that you can live with yourself and your family, and work productively.

I shall be very pleased to hear how you are progressing.

With all good wishes-it is still early enough to add-for a happy new year, Yours sincerely, $[\mathrm{ML}]$

I had no recollection of that letter. I wonder what I thought about it at the time; I doubt I was able to take in her not-so-hidden prognostication that all would not be well in the future.
} 
The diary begins well after the move to Bethesda, several weeks into the depression. I describe feeling like an emotional "zombie" when depressed, incapable of shedding tears. ${ }^{44}$ What comes through is that even when I was feeling functionalwhich often happened in the evenings ${ }^{45}-$ I had no belief that things would "work out." I was a new mother overwhelmed by the responsibilities and, even with the partnership of my spouse, couldn't imagine that we could ever care for the baby, take care of all that day-to-day life required and hold down two jobs. In fact, we rather quickly found and hired Mrs. S, a wonderful housekeeper who came five days a week to care for Josh and the house. Even so, it all seemed so unimaginably impossible. ${ }^{46}$

${ }^{44}$ See supra, text at note [].

${ }^{45}$ Here's the entry from July $13^{\text {th }}$ :

10:55 [A.M.] - Numb, as bad as ever for past few hours. Woke after 8 - baby still sleeping [discontinued].

7:45 P.M. - Zombie like most of day [.] But around 5 P.M. or so got energy which has lasted till now. Aware that tom'w morn will probably be bad again. Sort of straightening up so woman coming won't reject job - but can't believe she'd take it on unless in real need of position now.

11:35 - Have felt good \& been active all evening. But it's like having terminal cancer and knowing there may be a cure, but that you won't live long enough 'till it's discovered - But for awhile you can forget that you're ill and enjoy life. Almost hate to go to sleep, for I may never feel this way again. • .

${ }^{46}$ On July $14^{\text {th }}$, at $12: 40$ P.M., I wrote:

Have felt "old self" again \& can runabout house doing chores \& taking care of the baby-but never believing it can work out, only forgetting temporarily that it can't.

I record that also on that date, I presented my new psychiatrist, Dr. Z, with a written brief to prove my case that things couldn't work out:

1) I haven't learned how to care for the baby myself in almost 4 mos-that won't change in 3 weeks [when $\mathrm{J}$, my husband, was to begin work].

2) Even w/help I can't care for baby \& keep house-I haven't been able to do it even w/J's help.

3) I don't believe Ill be able to drive right away (a) because of Elavil and (b) because we'll never get around to buying a second car before $J$ goes to work.

4) There are no stores around here to walk to [therefore] I can't run any of the millions of errands we'll have to do. 


\section{As I mentioned above, ${ }^{47}$ I would cycle in and out of functional periods. ${ }^{48}$ When functional, I was a flurry of activity and competence. ${ }^{49}$ When down, I lacked the energy}

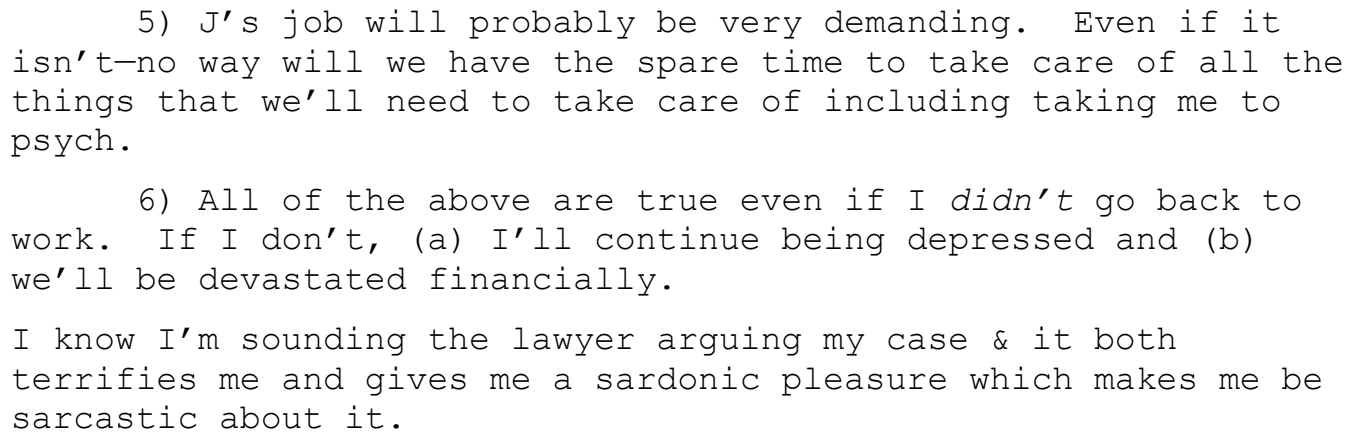

Each of my depressive episodes has been marked by a conviction of hopelessness. Clever as I am, I have always found a reason to distinguish prior episodes from which I had recovered, sure that the current episode would be my doom.

${ }^{47}$ See supra, text at note [].

${ }^{48}$ What surprised me in rereading the diary was the length of these periods. Although at first the ups and downs varied day by day, after awhile most periods would last about two weeks each, and this only ended during the time I spent at a day treatment program. See infra text at notes []-[].

${ }^{49}$ I believe I displayed fairly classic symptoms of hypomania. See, e.g. Brunilda Nazario, M.D. (reviewer), Hypomania and Mania in Bipolar Disorder, available at http://www.webmd.com/bipolardisorder/guide/hypomania-mania-symptoms (2010) (last visited Feb. 18, 2010) ("Hypomania is a less severe form of mania. Hypomania is a mood that many don't perceive as a problem. It actually may feel pretty good. You have a greater sense of well-being and productivity."); Definition of Hypomania, MedicineNet.com, available at http://www.medterms.com/script/main/art.asp?articlekey=30745 (Law Editorial Review: Feb. 18, 2004) (last visited Feb. 18, 2010) (explaining that "[h]ypomania is similar to mania but less severe. The symptoms are similar with elevated mood, increased activity, decreased need for sleep, grandiosity, [and] racing thoughts . . However, hypomanic episodes differ in that they do not cause significant distress or impair one's work, family, or social life in an obvious way."). The Diagnostic and Statistical Manual of Mental Disorders, Fourth edition, (DSM-IV) defines hypomania as follows:

a distinct period of abnormally and persistently elevated, expansive, or irritable mood lasting at least 4 days that is clearly different from the individual's usual, nondepressed mood. During a hypomanic episode, three or more of the following (four if the mood is irritable only) must be present:

- inflated self-esteem or grandiosity

- decreased need for sleep (e.g., feeling rested after only 3 hours of sleep)

- more talkative than usual or feeling pressure to keep talking

- racing thoughts or thoughts that seem to jump from topic to topic

- distractibility (e.g., attention is easily drawn to unimportant details)

- increased goal-directed activity (either socially, at school or work, or sexually) or psychomotor agitation

- excessive involvement in pleasurable activities that have a high potential for negative consequences (e.g., going on buying sprees, foolish business investments, promiscuous sex).

http://bpd.about.com/od/glossary/g/hypomania.htm

What I don't know is whether the medication in any way contributed to these abnormal, excessively upbeat, periods. [discuss with Fischel]. 
to lift a finger to help with Josh, cooking, or any other household chore. Even worse, I was terrified that I-we-were doing serious, irreversible, emotional and physical damage to Joshua, whose life seemed to have no discernible pattern. ${ }^{50}$ Further, I was wracked by guilt for the emotional and physical stress I was causing J. ${ }^{51}$ And I continued to remain convinced, even in my functional periods, that the three of us were ultimately doomed. On July $17^{\text {th }}$, I conceived of what I believed to be the only possible, albeit not likely, solution-that we should put our baby Josh in foster care while we got our acts together:

10:10 PM: I am now in Joshua's room while he is playing in his crib. I held him in my arms tonite, rocked him, sang to him, and wept for all of us. I wished so much that I was wrong and that $J$ and Dr. Z might be right. And then I thought of one possible solution, but it would only provide a slim chance. That would be to put Joshua in a foster home while J and I both went for analysis or some other kind of psychological counseling. I

${ }^{50}$ Also on July $14^{\text {th }}$, I wrote:

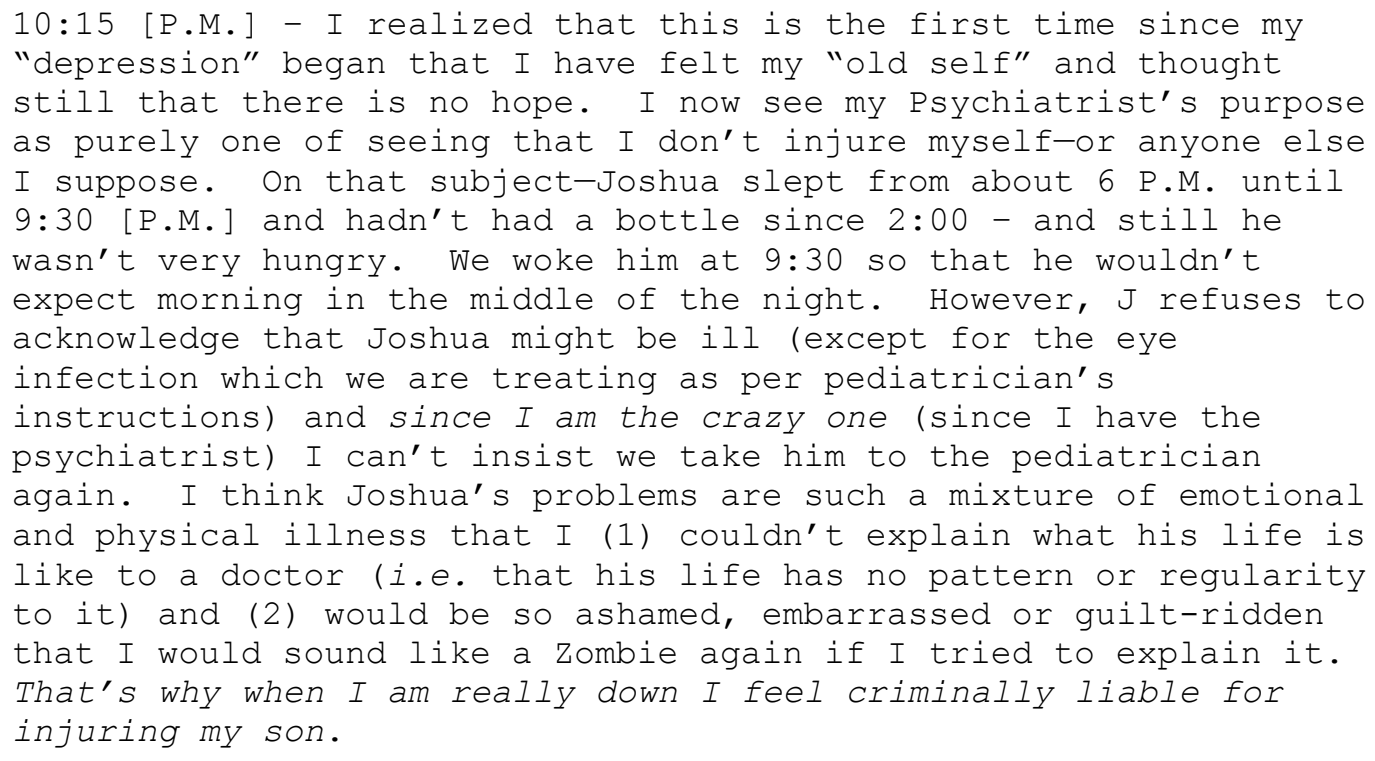

(Emphasis added.) Martha Manning expresses a similar sentiment in her essay The Legacy in [Nell] at 256, 267 ("As a psychologist whose profession had historically enjoyed mother-bashing as a blood sport, it was easy to apply it to myself. My daughter would be ruined for life and it would be all my fault.")

${ }^{51}$ On July $15^{\text {th }}$, Mrs. S's first day with us I wrote:

[Mrs. S] will leave before we'll have to go to psych... and if I can't or won't push myself to help J when we get home, our life will degenerate into what it was last week and I'll have to watch $J$ _ killing himself while I'll just feel horribly guilty and frightened.

(Emphasis added.) 


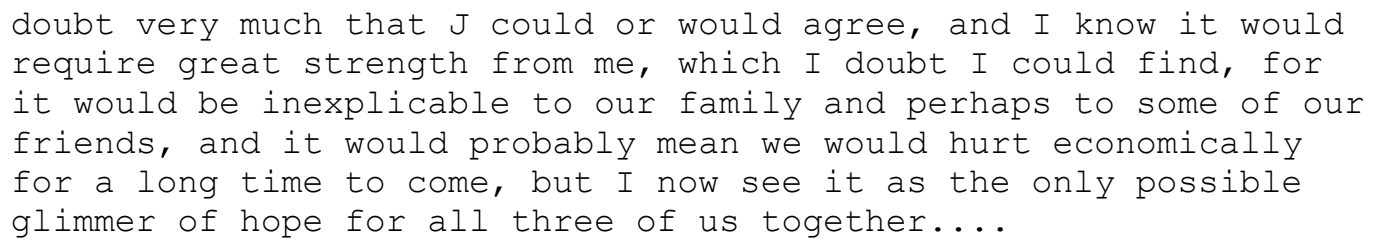

11:25 PM: Oh God, what a catharsis this idea is! Finally I have found a solution to the problem I thought had none, which makes sense to me!

Of course, this "solution" did not make sense to J, and my elation over the idea

left him quite distressed. Afterwards, this idea would seem as crazy to me as it must have to everyone else with whom I shared it. Looking back, I am unable to discern whether these apparent distortions in my thinking were caused by the depression, ${ }^{52} \mathrm{my}$ immaturity, or, more likely, some combination of the two. Yet in the midst of such hopelessness, something in me was struggling to survive, and I see those distortions as part of that struggle. ${ }^{53}$

Joshua meanwhile was doing fine, despite all my fears that I had "ruined" him.

His colicky behavior abated, his schedule became more regular, and I wrote that he was "becoming much more real to me." 54

52 See supra note [] and accompanying text [on distorted cognitive functioning].

${ }^{53}$ On July 19, 9:20 A.M., I wrote:

It was difficult to drag myself out of bed when Joshua was crying around 7:15, but I did it and today we introduced him to rice cereal-his reaction was ambiguous. Today the problems ahead again seem large \& difficult, but I at least realize that the sun will rise again tomorrow. [July 23:]

Have not written in days because I have sunk back into zombie-ism-and the intellectual challenge no longer exists. I have become such a monster that I no longer want to go on livingyet I lack the courage to take my life. I know that to get better would require extraordinary effort-more than I wish to make. I don't know what I'm waiting for, but the waiting is agony....

10:30 - Have returned from Dr. Z's feeling renewed. He suggested I investigate the possibility of going back to work sooner, part time. Although it seems very unlikely to me that it will work out, I really6 have nothing to lose.

So we shall see.

${ }^{54}$ I wrote this on July $27^{\text {th }}$. However, I also wrote that I still regretted "having borne him. But being in touch with those feelings and not feeling guilty about them may be a good sign in my mental recovery." 


\section{Then something truly awful did happen, something that confirmed my fears that I}

\section{was truly hurting J:}

\section{August $2^{\text {nd }}, 11: 15$ P.M.:}

The agony I irrationally expected two weeks ago has materialized. $\mathrm{J}$ is hospitalized with acute gastrointestinal bleeding. My mother and [J's father] are here, and I am presently relatively calm and functional. The baby is appropriately asleep. J lies alone in a depressing strange hospital room and I am here, too stunned to react with tears. I fear he may die, and I can't envision life without him. If he lives, I don't know where to find the strength to nurse him back to health. Thank god for medical insurance, but what income are we, or I, to live on? These problems are too immense to be of real present concern. I tremble for him lying there alone and frightened. And regardless that it does no good, I feel somewhat guilty for causing so much stress, which, if it didn't directly cause the problem, resulted in his smoking and drinking more, which apparently, with his use of [a potent pain killer] likely caused the bleeding.

Last night, at $3 \mathrm{o}^{\prime} \mathrm{clock}$ this morning, J went to urinate and fell down. I ran into the bathroom, his eyes rolled, his legs kicked involuntarily-he had become faint. I called his father, but waited till this morning to call the doctor. We rushed him to suburban hospital at 8:30 A.M. His blood count is poor and he has already received 4 units of blood. A minor operation revealed no serious lesion of the stomach, but rather generalized bleeding...

I feel myself growing faint. I fear my own physical health is not good... ${ }^{55}$ I feel, however, hypochondriatic, 56 I fear my mental health most of all. I don't know what will be...

\section{August $9^{\text {th }}$ :}

A whole week has passed. $J$ is still in the hospital and my mother will leave tom'w evening. The week has been various shades of hell, but I am now in a state of what I can only describe as numb contentment. From worrying so about $\mathrm{J}^{\prime} \mathrm{s}$ health and life to becoming so absorbed in my own insane state and refusing to try to "rehabilitate" myself to now being functioning, happy, anal, articulate, and everything the "old" Margi used to be (so that my mother plans to go home happy and relieved)-except that my husband lies ill in a hospital, and I feel no pain, no worry, no loss. I again explained to [Dr.] Z that this state, tho preferable to all my other post-crisis states, is as unreal and as insane as any other, and that calculating all the stresses working on me (and J) right now, I do not believe there is any hope for anything but a tragic ending.

\footnotetext{
${ }^{55}$ I experienced, during this and other episodes, a variety of physical discomforts. My fears ranged from cancer to heart disease, yet repeated physical examinations revealed no such pathology. See Solomon at 26 ("sometimes ... depression is confused with the physical ailments through which it is experienced.") ${ }^{56}$ [cite to prevalence of hypochondria among depressives].
} 
I have spent much time discussing my state with my father-in-law. Just as the intellectual chess game I thought I was having with Z, I now enjoy the development of a new relationship with my father-inlaw. Again, no matter how bad life gets, it's still worth more than nothingness.

\title{
August $11^{\text {th }}$ :
}

J came home tonight. Instead of joy, I feel fear and depressed. Now he needs care, much as I did when I came home after giving birth. Now his father will leave and we will be faced with the responsibility for each other-and I fear my ability to care for us. His return is no magic pill to cure my depression. He is still full of pipe dreams and great expectations. Whatever sense of mortality he felt when he entered the hospital has now disappeared. To him the days ahead contain infinite hours. He still is precious enough to calm my tears by saying he's come home to take care of me-but he forgets too fast what that burden will become. I feel "sane" now, but still fear catastrophes that lie ahead-there will be no sudden relief to all this pain-and future pain-and I still can't believe I will face that challenge in a positive way. I again fear the ruination of my life, and the lives of those most dear to me.

\section{August $13^{\text {th }}$ :}

\author{
We're on a seesaw. J developed an excruciating headache and I \\ "rose to the occasion" as my parents like to say. I, alone, took \\ Joshua to his new pediatrician-and everything went smoothly. I also \\ ran out to the drug store at 10:30 P.M., with the baby, to get J \\ drugs while he soaked in the tub. Plus I fed the baby, cooked a \\ chicken, ate my dinner, cleaned up, etc. etc. And one of the \\ crowning achievements of the day was putting Joshua down awake and \\ quiet and have him fall beautifully to sleep. But tomorrow has a \\ morning, and we'll see how that goes.
}

So that crisis passed, J recovered, and my life continued its cyclical pattern.

When I next wrote, more than two months later, I was in my second day at a community mental health day hospital, and the diary entry was intended to fill in the gap of what had transpired over that period of time, "so that in the case of a future I don't expect to have, I will be able to look back on all of this." ${ }^{57}$ I describe what happened after I started my new position at the Office of General Counsel of the United States Food and Drug Administration (FDA). ${ }^{58}$

\footnotetext{
${ }^{57}$ Entry, October 23, 1975. I continued: "And also, there is no doubt that I also want to leave something for posterity-immortalize my over-inflated impression of myself."

${ }^{58}$ After a federal clerkship, in 1974, I accepted a position as an assistant regional attorney at the United States Department of Health, Education and Welfare (HEW). As FDA was a subdivision of HEW, I was able to "transfer" to that office for the period of time that J and I would be in Washington, D.C. The
} 


\section{October $23^{\text {rd }}$ :}

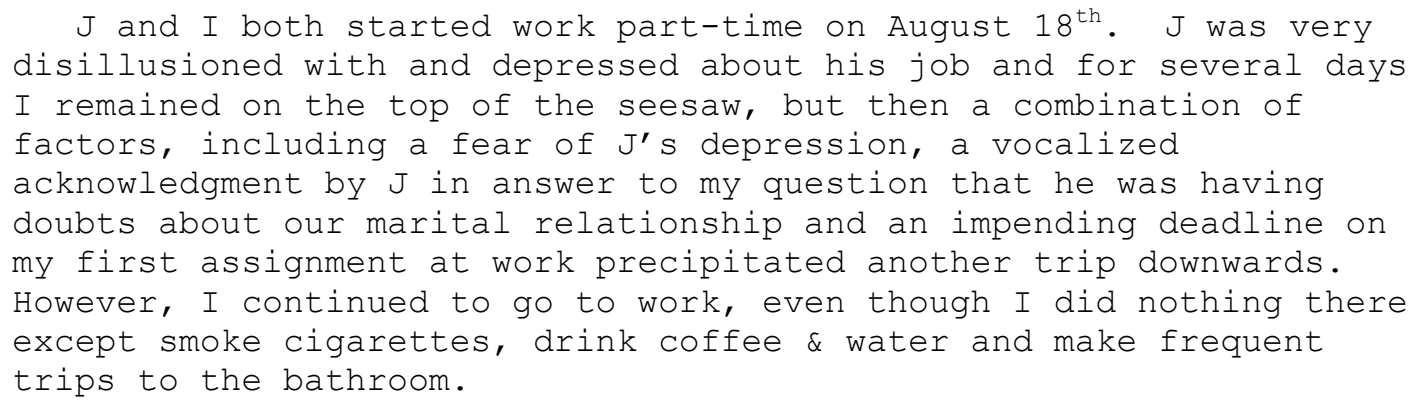

Rereading this entry evokes vivid, painful memories of sitting at my desk for hours and days on end, staring at printed cases and blank sheets of paper, and being incapable of forming a coherent thought.

Because I have hidden from the outside world for most of the time I was in a depressed state, ${ }^{59}$ I have largely shielded myself from the humiliation of being dysfunctional in my professional world. ${ }^{60}$ Unlike many others who have suffered the "noonday demon," 61 I never struggled with reconciling depression and work on a dayto-day basis, for when I got depressed, I just "dropped out" until I felt well enough to return. Being out in the world felt decidedly unsafe, as I was incapable of taking in my outside surroundings, distracted by the obsessive thoughts in my head. Being among normal people going about their everyday business, too, was a vivid reminder of how not normal I was. This period of time at FDA was an exception to that pattern. I was incredibly fortunate that Richard Merrill was General Counsel of FDA then. ${ }^{62}$ He had never met me as a "healthy" person, and yet throughout my time at FDA, he did

General Counsel's office was located in Rockville, Maryland, not far from where we were living in Bethesda.

59 "[O]n Thurs, Fri, Mon \& Tues stayed home altogether, mostly up in my room smoking cigarettes and playing solitaire." October $23^{\text {rd }}$ entry. I have memories of sitting on my bed drinking iced tea, chain smoking cigarettes, and playing endless mindless games of solitaire, while Mrs. S kept house and took care of Joshua. I wondered what she made of me. ${ }^{60}$ For that reason when I was asked to write a piece for the New York State Lawyer Assistance Trust (LAT) quarterly newsletter about depression and the legal profession based on my own experience, I declined. See text at notes []-[] infra for a description of my involvement with LAT. It wasn't until I read James Jones' essay, supra note [], that I realized I did have a relevant story to tell.

${ }^{61}$ See generally SOLOMON, supra note [].

${ }^{62}$ Both before and after his stint with the then new Carter administration, Richard Merrill was a professor at the University of Virginia Law School. 
everything he could to accommodate my needs and facilitate my recovery, including allowing me to "be" at the office despite my not producing any useful work product for periods of time, as I cycled in and out of depressive episodes. He was the first of several employers/supervisors who, despite the prevailing stigma and misconceptions about depression, enabled me to continue on at times when I was certain I had doomed my prospects for any professional future. ${ }^{63}$

What strikes me as I write about this period in my life is how easy it was to think about writing my story in the abstract-I thought I could do it in a matter of weeks during the summer of 2008-and how hard it is in reality to revisit these incredibly painful memories. ${ }^{64}$

I think, too, about Elyn Saks' repeated descriptions of blaming herself for not trying hard enough, for seeing herself as evil. ${ }^{65}$ Depression envelops one like thick soup, like mud. It's hard to move through mud-but not impossible. Every time I gave up trying, I felt evil, for the burden then fell on someone else. At that time in my life, it most often fell on J. It's hard not to feel shame in describing that time. I'm not one to spend

\footnotetext{
${ }^{63}$ Nancy Mairs describes being similarly blessed with an empathetic employer: "This calm man. . .rescued my life." Mairs, supra note [], at 207.

${ }^{64} \mathrm{I}$ am reminded that in his essay, James Jones shares how difficult it was for him to complete its writing James, supra note [] at 369-71. Although writing about this doesn't jeopardize my emotional health the way it appears to have for James, I do find it difficult to work on this for sustained periods of time. See also Donald Hall, Ghost in the House 162, 168, in CASEY, supra note [32] (relating how it pained his wife, Jane Kenyon, to write her poem, Having it Out with Melancholy); SOLOMON at 13:

I was frequently asked, as I wrote this book, whether the writing was cathartic. It was not. My experience conforms to that of others who have written in this field. Writing on depression is painful, sad, lonely, and stressful. See also SOLOMON at 91.

${ }^{65}$ See, e.g., SAKS, supra note [] at 55, 56 ((describing her feelings of being unworthy of basic things, such as speaking long-distance on the telephone with her family or friends, while recognizing that this believe came from nowhere but herself. "It's wrong to talk. Talking means you have something to say. I have nothing to say. I am nobody, a nothing. Talking takes up space and time. You don't deserve to talk. Keep quiet." Not long after this feeling began, Saks's conversations became solely monosyllables. Soon, she felt even more unworthy... "I am bad, not mad. Even if I were sick, which I'm not, I don't deserve to get help. I am unworthy."); id. at 60 (The doctors at the psychiatric division of Oxford's medical school wanted Saks to become an inpatient, and she ran out, refusing. That evening, she had a mantra running through her head; "I am a piece of shit and I deserve to die. I am a piece of shit and I deserve to die. I am a piece of shit and I deserve to die." Luckily, she returned for inpatient treatment the next day.); $i d$. at 67 (Saks's reasoning for not taking the suggested prescription medications was that "[p]eople ought to get better because they work at it, not because they take some pill ... Taking pills is cheating. . I'm not sick . .. I'm bad.").
} 
much energy on past regrets; I often counsel my students to put the past in the past and move on, to start afresh in the present. But there it is.

As the ups and downs continued, Dr. Z recommended I consider a day treatment program. On September $25^{\text {th }}$, J and I met with a doctor from the Potomac Foundation, a privately-run community mental health day care center in Bethesda, in close proximity to our house. But I was in an "up" phase, and over the weekend that followed, I really had a sense that I was making long-term progress and wouldn't need the program. A little over a week later, however, I sank again.

My highs during this time were incredibly high. I didn't go on manic spending sprees $^{66}$ or believe I could leap off tall buildings and fly, but the descriptions in my diary certainly suggest my emotional swings were other than from depressed to normal. ${ }^{67}$ When I sank again in early October, Dr. Z suggested that it might be time to reconsider Potomac, as well as consider other medications, such as lithium. Lithium is a powerful drug, normally (but not exclusively) prescribed for the treatment of bipolar disorder. ${ }^{68}$ । reacted angrily:

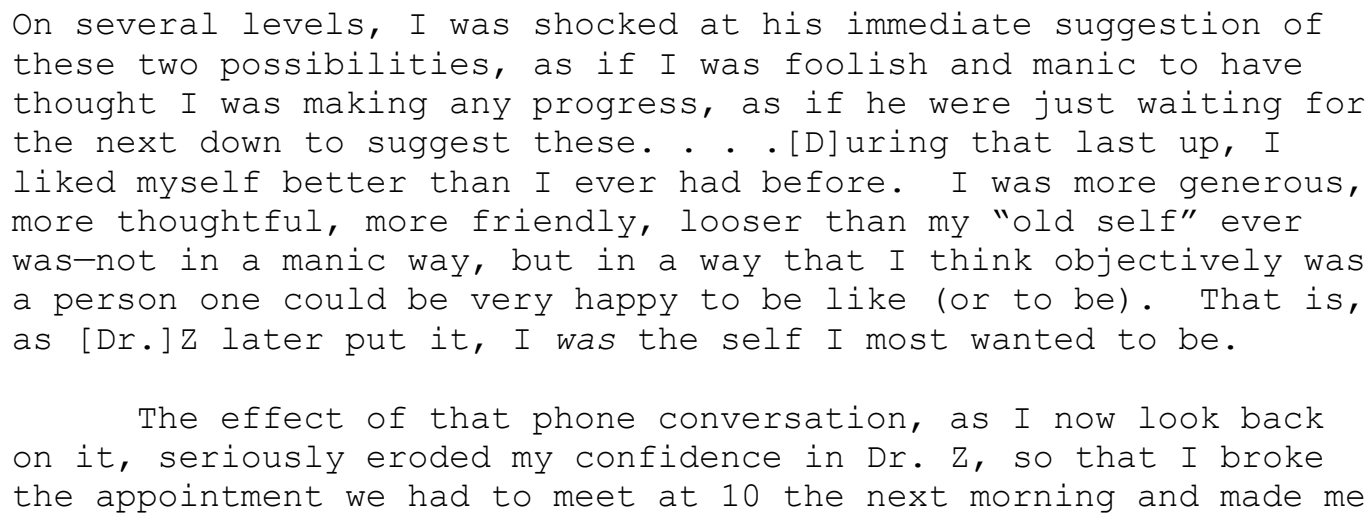

\footnotetext{
${ }^{66}$ Although I recall thinking I had come close when I purchased a second set of everyday dishes on sale that I didn't need! (They were, however, objectively speaking, a bargain.)

${ }^{67}$ See, e.g., supra notes [].

${ }^{68}$ See MedHelp, http://www.medhelp.org/lib/lithium.htm (last visited Jan. 29, 2010) (“Some patients who have not responded to (tricyclic) antidepressants, even after several weeks of treatment, have been given lithium along with their antidepressant \& have shown significant improvement."); Bipolar Disorder Treatment - Lithium, MentalHelp.net, http://www.mentalhelp.net/poc/view_doc.php?type=doc\&id=11213 (last visited Jan. 29, 2010) ("The American Psychiatric Association recommends lithium as first line therapy for bipolar disorders.”); Mayo Clinic, http://www.mayoclinic.com/health/lithiummedication/MY00639 (last visited Jan. 29, 2010) (explaining the high frequency that lithium is used to treat depression).
} 
completely despondent of deriving any benefit out of meetings with him during the down. I started smoking more cigarettes and taking worse care of myself and avoiding anything having to do with Joshua, than I ever had before. And I felt completely evil and guilty that I was doing nothing to help J (or R, L and A who came last Friday to stay a week), who has been running ragged between work, chores, Joshua (who has begun to wake up during the night). . ${ }^{69}$

\section{About a week later, I began the day program at Potomac:}

It was an incredible shock to face the reality of a hospital environment-even the day hospital. All along I've been crying put me in [a] hospital, but what I really meant is put me in a haven where I can get rid of all my problems, or give me 24 hours a day psychiatric help with someone of Sigmund Freud's credentials. But to face the reality of a hospital environment is something quite different. I want to deny that I'm as "sick" as the other patients. I can't anticipate spending day after day in one monotonous environment, with only an hour or so of group therapy to look forward to each day. I kept trying to think of alternatives to being here, but there are none that I can accept. And whether because the contrast of home with this place after a day here, or a renewed desire to get better faster, or an unconscious renewal of faith in the possibility of getting better, I don't know. But I had more mental energy last night, and consequently more physical energy, than I had had for a long time previously. And today I'm in relatively good shape-not happy, but in an up semi-numb condition. I feel articulate and more like my aggressive old self. Still, I anticipate only tragedy to befall me, and Joshua, and likely J-and I fear that any recovery from my problems will be a form of being which I could not now accept. ${ }^{70}$

I didn't write in my diary between October $23^{\text {rd }}$ and December $14^{\text {th }}$, and this would turn out to be the last entry. I write at 6 A.M. on December $14^{\text {th }}$ :

\footnotetext{
Life has become unbelievably exquisite. The depression has passed. I am reborn. I love me more than I ever have and now I love another. ${ }^{71}$
}

\section{Whether cause or coincidence, I emerged out of my depression during my}

several weeks at Potomac. However, my marriage to J did disintegrate during this

time. It turned out-much to my surprise-that he had fallen for a law student while a

\footnotetext{
${ }^{69}$ October $23^{\text {rd }}$ entry.

${ }^{70} \mathrm{Id}$.

${ }^{71}$ As further evidence that I was in something other than a "normal" state, I write, "I barely sleep anymore. But it isn't anxious insomnia. It's the insomnia of bliss, of reliving the best moments I have shared with B. . . . I slept a total of 13 hours in 4 nights during the week. December $14^{\text {th }}$ entry.
} 
Teaching Fellow at Columbia the year preceding our move to Bethesda, the year I was pregnant with Josh. Although this relationship was never consummated-she, too, was married-he continued to see her on trips back to New York when I thought he was visiting other friends. He was, however, deeply conflicted over whether he wanted to leave our relationship, but he was also terribly unhappy in Washington, even-perhaps especially?-during my periods of remission. ${ }^{72}$ I, not to be outdone, developed an intense romantic attraction to $B$, another lawyer at FDA, who, it turned out, was struggling through his own clinical depression at the time. ${ }^{73}$

This "up" period lasted from October until June 1976.

In February, J moved back to New York and I remained in the house in Bethesda. As much as I thought I was ready for our marriage to end-or at least experience a long hiatus - I deeply felt the loss of a relationship that at that point had lasted for more than a decade. $^{74}$

I was at that time, as I often lamented, a "monogamous virgin," never having had sexual relationships with anyone other than J. I rapidly proceeded to make up for lost time, and I shudder when I think of the chances I took with utter strangers during 1975 and 1976, in this, pre-AIDS-awareness era. Yet I undeniably had a wonderful time in many ways. The cycling had stopped. I felt alive again, vital, capable. I had survived, and I now savored life in a way only those who have faced losing it can appreciate. I liked my work, I made new friends, I had a rich social life, as well as a precious little boy whom I adored. Life seemed really good. ${ }^{75}$ I phased off my medication. I was me again, only better. Carpe diem.

\footnotetext{
${ }^{72}$ It bears acknowledging that these are my perceptions, not J's. From his perspective, his feelings for the other woman were the result of an unhappy marriage, not the cause, and my depression had nothing to do with it. I certainly agree that with respect to physical intimacy, I did not hold up my end of the marriage. ${ }^{73}$ Unlike how my depression manifested, B was able to function brilliantly while on the job; his demons attacked when he left the office. Nonetheless, we both felt we had found kindred spirits, and although the attraction remained unconsummated until much later, it was enormously powerful.

${ }^{74}$ I recall that for weeks seeing a husband and wife hugging on TV would trigger uncontrollable fits of crying.

75 "My job is everything I could want in a job. The people are an incredibly warm group and their competence as attorneys (and secretaries) is exhilarating. B thinks, and he's probably right, that [FDA OGC] is one of the finest law firms in the city. So my love life, my job, my son, . . and my recovery are overwhelmingly wonderful". Id.
} 
I moved from the house in Bethesda to a smaller one in Chevy Chase. As I recall, the landlord wanted the Bethesda house back in order to sell it, and I had no need for such a large place anyway. Rather than move into an apartment-a move that would have made sense in so many ways - I looked for and found another house.

Moves are always stressful, but I don't recall being fearful that I would fall apart again. Yet fall apart I did, and it all seemed to happen so fast. Once the furniture was unloaded in the new house, I immediately regretted the choice I had made. No, that doesn't capture it; I immediately felt the overwhelming anxiety that had precipitated the first depressive episode. I called J in New York and told him I couldn't manage, that I was falling again, and, as I had Joshua with me at the time, ${ }^{76}$ he immediately drove down to Chevy Chase.

I no longer recall whether it was that same evening, or whether a day or two had passed, but J developed a terrible headache one night, took several pills, and went to bed. I knew (or thought I knew) that there was no way he would wake up when Joshua woke in the morning. I was terrified of having to assume responsibility for Josh. Perhaps I was fearful as well that J would have a relapse of the bleeding that had landed him in the hospital. I couldn't face the morning. So I swallowed what was left of a bottle of Valium and went to sleep.

Thus began my first in-patient psychiatric hospitalization. The next morning J did awake, figured out what had happened, called Dr. Z, and, at his direction, drove mestill largely unconscious and with the baby somehow strapped on top of me-to Sibley hospital. Vomiting was induced-apparently the amount I took would not have been enough to kill me-I was admitted, and I remained there for about three or four weeks. $^{77}$

\footnotetext{
${ }^{76} \mathrm{~J}$ and I were sharing physical custody of Josh at this point.

${ }^{77}$ Although I don't recall the dates exactly, I think I was there for the celebration of the nation's bicentennial on July $4^{\text {th }}$.
} 
In retrospect, Sibley was probably as good a place as I could have hoped to be at the time. ${ }^{78}$ I recall little, but I certainly improved while I was there.

My parents had been terribly distraught over J's and my break-up, and the recurrence of my depression only exacerbated their distress and their anger at J, whom they (understandably) blamed for abandoning me. However they were there for Joshua, whose care they shared with J, and they were there for me, in any way that I needed them. When I left the hospital, they urged me to return to New York. I resisted; my new life was in D.C., including my work. ${ }^{79}$ They stayed with me awhile, but obviously that couldn't last indefinitely, and even I did not feel ready to be completely on my own. The solution was one that I recall with dread.

My parents hired a "companion" for me. The only criteria as I recall was that the person be able to drive and cook. As the compensation they were offering was minimal, the applicants for the position were hardly stellar. They settled on an older woman who would live in, cook for and drive me to work or doctor appointments as necessary. I no longer recall her name, but in my recollection, she was anything but a companion. She was a creepy stranger living in my house. When I was well enough to socialize or date, her presence was an extreme embarrassment. When I wasn't well enough - I was still cycling-she just completed the picture of hopelessness that pervaded my thoughts. I was back on medication, however, which if not effective in "curing" the cycling, nonetheless kept a bottom on how low I plunged; another suicide attempt was not a threat.

I recall her driving me to work and I recall days of once again staring blankly at whatever task I had been assigned, incapable of completing it. This continued throughout the remainder of the summer. I was not getting better. My parents again remonstrated with me to return to Long Island where they could care for me and, in September, I finally acquiesced.

\footnotetext{
${ }^{78}$ My recollections are only impressionistic. But I recall being treated well and never feeling demeaned, as I was to experience many years later at a different hospital. See infra, text at note [] (describing experience at Mt. Sinai hospital in 1985).

${ }^{79}$ FDA made it clear that I was welcome to return whenever I felt able.
} 
Dr. Z arranged for me to see a new therapist, Dr. B, whose office was in

Manhattan. So twice a week, I took the train into New York for my appointments. Otherwise, my life consisted of hanging around my parents' house, caring for Joshua when I was able to, ${ }^{80}$ and continuing to feel, for the most part, that I would never feel ordinary, normal again. I did a lot of reading during this time, favoring books about others who had suffered mental illness, including The Snake Pit ${ }^{81}$ and The Bell Jar. ${ }^{82}$ At some point, however, the cycling stopped; I have no recollection of when that was.

Eventually, I began to venture further from the "comfort" 83 of my parents" house. I would take Joshua, who by then was almost a year and a half old, and toot around the nearby village of Roslyn, with its New England preciousness, lovely shops, galleries and a huge duck pond Joshua and I both loved. In one gallery, I was struck by a strikingly handsome, rather bohemian, artist who manned his father's shop. D and his father were both enamelists. The attraction was mutual, and before long, I had resumed a sexually-active life.

D was great with Joshua, adored me, and provided me with an escape from the "parent trap." In a very short time, we decided to take an apartment together. By February 1977, we were living in a lovely garden apartment complex on Manhasset Bay,

\footnotetext{
${ }^{80}$ During this time, J and I shared physical custody of Joshua. He alternated weeks with each of us. This arrangement continued until Josh began college in 1993. At the time we began "co-parenting," there didn't even exist a name for our arrangement. Then in [], a book appeared, written by a New Haven couple, who "invented" the concept of co-parenting. Their book does not appear to be in print any longer, and I have been unable to find it. [have RA's do search]

${ }^{81}$ Mary Jane Ward, THE SNAKe PIT (1973).

${ }^{82}$ Sylvia Plath, THE BeLl JAR (1971). Others describe a similar hunger to read the accounts of other depression sufferers. See Meri Nana-Ama Danquah, Writing the Wrongs of Identity in CASEY, supra note [32]. at 173-74; Dorman, supra note [], at 236. But see Maud Casey, A Better Place to Live,, in CASEY at 292 ("I had read Kay Redfield Jamison's An Unquiet Mind twice, and took a stab at William Styron's Darkness Visible, but they had left me feeling even more depressed. How was I, a not-yet-published writer who didn't have the energy to turn on her computer supposed to feel better by reading the stories of depressed, famous writers?"). From there, however, she recalls "how often reading had saved my life," and decided to read the essay on depression by Laura Slater that her sister, Nell, had recently sent her. Id.

${ }^{83}$ In fact, the better I felt, the more oppressed I felt in their home. In so many ways, we all returned to the moderately dysfunctional family we had been during my adolescence; I certainly didn't feel like an adult when I was with them.
} 
and I returned to work at the office where I had begun my career as a lawyer. ${ }^{84}$ It was great to be back, in every way.

The only problem was D's alcoholism and drug addiction.

I don't recall when I first became aware of it, but I'm fairly certain it wasn't until we started to live together. He was sweet and loving when sober, angry and belligerent when high. Nor did it take me long to realize that he wasn't going to change, and I wasn't going to put up with it. Happily, the break up went relatively smoothly, as I recall, with a minimum of drama. He moved out in the summer of 1977, and I resumed a fairly fulfilling personal and professional life. I renewed old friendships, made a number of new friends, and, while my soul mate didn't appear, I didn't often lack for male attention or company. By now, J and I had a regular pattern of sharing Josh on an every other week basis, ${ }^{85}$ which gave me tremendous flexibility for both work and social life. The life that had seemed impossible in Washington after Josh's birthday now seemed quite manageable, even given my commute, which required (on the weeks he was with me), driving Josh to the babysitter early in the morning, returning to my apartment complex, hopping on the jitney to the train station into the City, taking the subway downtown, and then reversing the whole process in the evening. Joshua seemed to be doing just fine, and I both enjoyed the time I had with him, and welcomed my freedom when he was with J. ${ }^{86}$

\footnotetext{
${ }^{84}$ This was the Regional Attorney's Office, Region II, of the now defunct Department of Health, Education and Welfare.

${ }^{85}$ See supra note [].

${ }^{86}$ In fact, Josh seemed to be amazingly well adjusted and happy, especially given the turmoil surrounding his infancy. When he was three, we enrolled him in two nursery schools, one in the city, where $\mathrm{J}$ was living, and one in Port Washington, near my apartment. The city school barely blinked at the arrangement; after all it was located on Christopher Street in Greenwich Village, and atypical family arrangements were hardly unusual there. The school in Port Washington was quite reticent, however, concerned about how a young child could possibly adjust to such an arrangement. Josh adjusted as or more easily than any other child, without any difficulty whatsoever. I have often speculated that it might have been because he was cared for by so many different people in his early years that he adjusted to new situations with such uncommon ease.
} 
As time went on, I didn't think much about my depressive "episode(s). ${ }^{87 \text { " }}$ They seemed to bear no relationship to the life I was then living, an aberration in a life that was largely normal.

Not that this time was without anxiety, however. There of course remained some concern that what had happened once could happen again. I would from time to time, have deeply disturbing dreams in which the depression had returned, and would wake up so grateful that they were only dreams. But for the most part, I recall this time as marked by a seemingly normal, manageable amount of anxiety, much as my life "before depression" had been. And this state of affairs continued, more or less, until November 1985

During that time, my personal and professional life was filled with rich experiences. ${ }^{88}$ For sixth months from fall 1978 to spring 1979, I was appointed Special Assistant United States Attorney for the Southern District of New York, Civil Division, through an arrangement worked out between the regional office of HEW and the S.D.N.Y. U.S. Attorney's office. The work was challenging, my colleagues terrific, and I learned a huge amount (while enjoying intense crushes on at no fewer than three assistants in my division). When I left at the end of my sixth month stint, I stepped into the position of Chief Regional Civil Rights Attorney, a newly created position within HEW's Office of General Counsel. When HEW split into DHHS and DOE in 1980, I went where the Civil Rights work and resources were greater, the Department of Education.

Also during this time I moved into New York City. While two nursery schools had been a workable possibility for Joshua, obviously kindergarten was a different matter. And I wanted to be in NYC, where my work and most of my friends were. (And where one was more likely to meet guys than in the suburbs!) Josh started kindergarten in the

\footnotetext{
${ }^{87}$ I have never quite determined whether the period from May 1975 until fall 1976 was one, long episode with a hiatus of "wellness," or two separate ones. In effect, it really makes no difference.

${ }^{88}$ I remember that often the phrase "the rich texture of my life" would go through my mind like a mantra. What a contrast to the image of the "murk" that characterized my memories of my life with my original nuclear family.
} 
fall of 1980, and we moved into a comfortable two-bedroom apartment in Stuyvesant Town that December. ${ }^{89}$

And then, in the fall of 1981, I met Doug at an American Sign Language (ASL) course at The New School. I was taking the course for three reasons. One, I wanted to learn a new language, either Spanish or ASL. Two, I decided on ASL because I had a deaf aunt and uncle with whom my communication was rather limited, and because I could get the feds, my employer, to pay for the latter; in theory, it would be useful in communication with the hearing-impaired in my capacity as enforcer of, among other things, Section 504 of the Individuals with Disabilities Act. Three, I wanted to meet guys. And I did. ${ }^{90}$ By the following summer, when Doug's un-air-conditioned studio had become oppressively hot, Doug moved in with Josh and me. Four years later, on November 17, 1985, we married. More on that later.

Big changes were occurring career-wise as well. In August 1983, I began teaching at New York Law School.

Even in law school, I had known I wanted to teach; having been one of a distinct minority who actually liked law school, I always felt that I was cut out for that life. But first I wanted to save the world, and if the work I did in the government didn't quite accomplish that mission, I nonetheless lost sight of my original plan for a period of time. ${ }^{91}$ It was only after I had been a supervisor for several years, with fewer and fewer opportunities to do hands-on lawyering, and after the frustrating strangulation of the

\footnotetext{
${ }^{89}$ Josh commuted with me from September until we moved. Even that went smoothly; he was such a terrifically "go with the flow" little guy.

${ }^{90}$ Doug was taking the course because he was, at the time, living with his girlfriend who was hearing impaired. The relationship wasn't going very well, and he thought this overture on his part might help. As with any language, one needed to practice, and he would attempt to do so with her. She, however, would remark condescendingly that what he was learning was not how deaf people actually signed. So, as I, too, needed someone to practice with, and as we had started walking home together, we agreed to practice with each other. One thing led to another and, as Doug likes to say, he learned to sign "bye-bye" to his girlfriend.

${ }^{91}$ In part, I think this was because J became a law professor in 1976, in the fall after he returned to New York, and without it being a conscious decision, I think I needed to separate my life from his as much as possible. In fact, even after we split up, my perception is that we remained emotionally dependent on each other in a not terribly healthy way for several years. It took us many years to finalize our divorce, even though there were no financial or custody issues to resolve. We had lived pursuant to a separation agreement that we had negotiated ourselves, and nothing remained to do but submit the papers.
} 
Office for Civil Rights by attrition during the Reagan years, that I "remembered" my original dream to teach.

Teaching was simultaneously wonderful and anxiety-producing. That's normal, of course, but it was exacerbated by worrying that I wasn't really good enough, wasn't smart enough, couldn't follow the esoteric theory spun out at many faculty colloquia. Sometimes, after a good class, I felt supremely confident. Oftentimes, however, after a bad class I was overwhelmed with self-doubt. Over the years, I have become convinced that while virtually all law professors feel this way, at least in the beginning years, it's generally only women that admit it to one another.

And that was one of the problems. I had no women colleagues with whom to share these doubts, from whom to receive the nurturing support that I would receive in later years. ${ }^{92}$ At the time I joined the faculty, there was only one other woman on the faculty, an older woman who kept to herself mostly and had been there many years. To say she wasn't especially collegial would be an understatement; she didn't even speak to me until the second semester, and then barely. And although I had some colleagues who were friendly, I never felt like I could just be myself. I always felt self-conscious that I was being judged by my colleagues, and that I wouldn't measure up. Most of us ate regularly in the faculty dining room, and I don't recall any frivolous, light conversations (with the possible exception of sports talk). My colleagues rarely even mentioned their children. I feared that if I talked about Joshua I would be judged as "not serious about being a scholar."

And there was that looming pressure to produce scholarship, which was not what drew me to wanting to teach. Although I had always been gifted as a writer, I hadn't written anything of a scholarly nature during the nine years since my clerkship. My first serious undertaking was a monster of a project, and I was all over the place. ${ }^{93}$ The good part was that it was based, at least in part, on my experience with the Office for Civil Rights of the Federal Department of Education; the bad part was that I had little

\footnotetext{
92 See infra [discussion of joining Touro faculty].

${ }^{93}$ It ultimately was published as The Uses and Abuses of Informal Procedures in Federal Civil Rights Enforcement, 55 GEO. WASH. L. REV. 482 (1987).
} 
idea of how to make it a cohesive, manageable, intelligible whole. And no one was assigned to mentor me through the process, although the same person who had chaired the appointments committee the year I was hired was, in my second year, the person designated to give me feedback on my "draft."

His feedback was not negative-he said something like, "it's clear you can write, which is not always the case (heh, heh)." But he (correctly) observed that it was organized more like chapters in a book than a law review article, and needed a great deal of work. My anxiety level shot up in reaction.

I had, at some point early in our relationship, shared with Doug my "history" of depression. By then, however, many years had passed, and while I certainly experienced periods of intense anxiety, especially since I had begun teaching, nothing approached the 1975-76 episodes and I never became dysfunctional. ${ }^{94}$

That changed, however, almost immediately after our wedding in mid-November 1985. Although the wedding itself was the joyous occasion it was supposed to be, after we returned home that night, I became very upset that we had inadvertently left the leftover food, which had been bagged for us to take home, on the curb when we packed the car afterwards. I couldn't sleep at all that night, as anxiety set in. It intensified the next day when we went to open a joint back account, and the woman at the bank insisted that, in order to deposit checks made out to "Mr. \& Mrs. Douglas Block," I had to use my married name to open the account, although I had no intention of changing my last name. It continued to build over the next week, so that by Thanksgiving I was quite certain that it wouldn't just pass, as other episodes of anxiety had. I remember tucking Joshua, only ten at the time, into bed one night, and he asked me what I was

\footnotetext{
${ }^{94}$ Not irrelevant, I suppose, to what was to follow, in August preceding our wedding, I received a message from my ob/gyn that my annual pap smear was abnormal. I remember getting the message at work and, before I was able to actually speak with my doctor, feeling panicked that I was about to die. My doctor ultimately reassured me to the contrary, and referred me to a specialist for follow-up. That doctor, whose name I have forgotten (or suppressed), confirmed by physical examination that I had moderate to severe dysplasia of the cervix. During the examination, while I was in the compromising position known only to women, this specialist, a man with a heavy eastern European accent, blamed me for the problem and scolded me for my promiscuity as the cause of my condition. Hardly the bedside manner to reassure a frightened young woman. When I had an abnormal pap several years later, I refused to return to this doctor, even though my (male) ob/gyn said he was, clinically speaking, the best in his field.
} 
nervous about. My answer was that I was nervous about being nervous. And that's what it was. Nothing concrete, no reason for the overall feeling of dread. It's not as if I regretted getting married, or that anything tangible was bothering me. Objectively, I had a really good life. But there was nothing objective about what was going on in my head.

Somehow I got through the semester, which, if I recall correctly, ended a week after Thanksgiving. I believe I had Doug come with me to school on the last day of classes, and whisk me away right after. Although my recollection is hazy, I think I managed to teach my last Civil Procedure class, but cancelled the last Administrative Law class, which was to have been a review for the exam. And then of course I felt tremendous anxiety about having done that. And how was I going to be able to grade exams? Or teach next semester? Or ever again? And then what would become of us? Worries upon worries, the internal, obsessive, constant and distorted ruminations so well described by others, ${ }^{95}$ consumed my every waking moment and prevented me from sleep, from appetite, from taking pleasure in anything. I insisted that Josh stay with J. Not only did I feel incapable of "taking care of him," I didn't want him to see what had become of me, and I didn't want to share Doug with anyone else. Doug was the only other human being I wanted around, ${ }^{96}$ and I feared having him leave me alone. He was freelancing at the time, ${ }^{97}$ so had more flexibility than most husbands would have had to stay home and care for me; but then his lack of earnings became yet another matter to pile on to the mountain of looming doom. And when he did have work, his parents would come into the city from Long Island to "baby-sit" me and to accompany me to my therapy appointments with B. I hated having them around, but I couldn't conceive of navigating the threatening streets of New York on my own. Everything scared me. I became completely dependent. I needed to escape, and the only place I could conceive of escaping to was a hospital.

\footnotetext{
95 [cites]

96 See Nancy Mairs, supra note [], at 183 (describing her experience with depression and that only her husband seemed real to her): "[My daughter, Anne], like everyone else around me, had long since ceased to seem real; only George was left to populate my world." Id.

97 At that time, Doug was a cameraman, mostly doing corporate shoots.
} 
I made an appointment to see $\mathrm{Dr} . \mathrm{B},{ }^{98}$ with whom I had stopped therapy some time before and hadn't seen since. I told him I needed to be in a hospital. It was pretty clear that he was used to dealing, at least at this point in his career, with more ordinary neurotics. Since I had been in much better shape when I began seeing him in 1976, he had never seen me in a state of such intense anxiety. He informed me that he "didn't do hospital work," tried to persuade me to hold off, to resume antidepressant medication. ${ }^{99}$ But although I began to take medication immediately, I insisted I couldn't wait the length of time it would take for medication to kick in; I needed relief NOW. ${ }^{100}$ He referred me to a colleague uptown who did do hospital work, Dr. Robert Fischel.

Doug and I met with Dr. Fischel and he, too, encouraged me to consider alternatives. I think I met with him a couple of times before I persuaded him to help me get into a hospital. He found me a bed at Mount Sinai hospital and it was there I went on December 6, 1985, just a few weeks after my wedding.

Meanwhile, my poor young husband ${ }^{101}$ didn't know what to do. Who was this stranger? What had happened to her? Did she need to be hospitalized? Could we trust this other stranger, this Dr. Fischel ${ }^{102}$ But I insisted on being hospitalized, and Doug certainly had no one else's expert advice on which to rely. So it was decided.

Doug's parents met us at the hospital; he needed their support and they were there for him. Even during the admissions process, I realized that the hospital was not the answer; my tormented mind was right there with me. I couldn't escape it by

\footnotetext{
${ }^{98}$ See supra note [].

${ }^{99}$ I can no longer recall whether he started me on antidepressant medication immediately, but I think he did. He certainly prescribed sleeping pills, but I still couldn't sleep. If I did, it was for no more than one or two hours a night. The rest of the night I would just lie in bed gripped by psychic pain. Yet I sought bed, wanting to go there soon after dinner - at which I was eating next to nothing-because being awake was torture, too. Because I hoped, in vain, to escape into the nothingness of sleep.

${ }^{100}$ Antidepressant medication often takes weeks, or even months, to begin to take effect. See National Institute of Mental Health (NIMH) Website, Mental Health Medications, http://www.nimh.nih.gov/health/publications/mental-health-medications/complete-index.shtml (last visited Jan. 30, 2010) (explaining that "[i]t can take three or four weeks until the [antidepressant] takes effect"); see also National Institutes of Health Radio, U.S. Dep't of Health and Human Services, available at http://www.nih.gov/news/radio/aug2006/08182006meds.htm (last visited Jan. 30, 2010) (explaining that antidepressants could take weeks or months to take full effect).

101 Doug was only 28 when we met, five years younger than I, and only 32 when we married. As I write this, Josh is 36, and the father of two children. Wow.

${ }^{102}$ I found it so painful to write about this, to remember just how overwhelming it must all have been for Doug.
} 
changing venue. I was wracked with indecision about whether to sign the voluntary admission form. By this time, Doug was getting really frustrated, and I think, perhaps, I ultimately signed to placate him. ${ }^{103}$

The hospital turned out to be hell. ${ }^{104}$ All I wanted to do was stay in my bed, uncomfortable though it was. But there were rules about getting out of bed, getting to breakfast, not returning to bed after breakfast. I was a "bad girl," resisting the rules, and that's how I was treated. I was not allowed to wear my own clothes until I started cooperating. I was not allowed off of the ward for other activities until I started cooperating. I was condescended to; no, worse. I was treated like a mental patient, with all the indignities that entails. I had no privacy. I recall having a gynecological examination, ${ }^{105}$ in full view of whoever might be passing by.

One night, I was aware of commotion around the bed of my elderly roommate, someone with whom I don't believe I ever exchanged a word. Did she have a heart attack? Did I just dream it all? No one would deign to tell me when I asked. And what about the night when I felt something cosmically horrible happening to me in my sleep that felt like a stroke, like something popping in my brain? Was it just a nightmare? I couldn't tell the difference, and still don't know. No caring person was there to comfort me, to allay my fears. What was I doing in this hell hole?

Fischel came to see me several times during my stay, though, and in those visits I again felt like I was still a human being. He took seriously whatever I told him and, I believe, was disturbed by my reports of how I was being treated by staff.

Doug came every evening. The trip from Stuyvesant Town often took him an hour or so each way. When he drove, he frequently had to pay for expensive parking. To the extent I could feel anything, my heart went out to him, but I was so grateful for his visits. He brought me anything I asked for, and things I didn't. Understandably, he didn't know how else to help. I complained that the mattress was terribly

\footnotetext{
${ }^{103}$ I remember the feelings, but specific memories are hazy, as is the case with so much that happened during this time.

${ }^{104}$ See SOLOMON at 75-76 (quoting an acquaintances suffering from depression who described Mt. Sinai as "'the most dehumanizing place I can imagine"')

${ }^{105}$ This exam was at my request; I was sure the dysplasia, or worse, had returned. As with all of my hypochondriacal concerns during my depressive episodes, this turned out not to be the case.
} 
uncomfortable, so he bought a pad. He brought me a Hanukkah present of perfume that I loved. It seemed so preposterous. My life was ending in a mental ward; what was I going to do with perfume?

J came to visit, without notice, along with Josh and J's dad. I was told I had visitors, went out to the visitors' room, and there they were. I was so embarrassed, especially for Josh to see me like that. They brought me a beautiful book of Renoir prints, an artist I had always loved. Josh must have been so confused. "I hope you feel better, Mommy." I can't remember whether I was already in the phase where I felt like an emotional zombie, but if my heart didn't break then, the recollection of that moment has always produced a deep ache in my gut.

I got better. I came home from the hospital on Christmas Eve, and was very glad to escape. I was anxious, but ready to try. The first day home, Doug went to work, and I went out by myself, bought groceries, and made a dinner. Something so simple, but just getting out of my internal ruminations long enough to focus on each step of the process was a real accomplishment.

But that didn't last. As with my original depression, my moods would spiral up and down from fully, ecstatically functional, ${ }^{106}$ to my being incapable of getting out of bed. Somehow, I managed to get through grading my exams, using the times when I felt relatively normal to do so. ${ }^{107}$ But I couldn't envision returning to teaching in January and, while Dr. Fischel and Doug tried to persuade me to hold off deciding, I both felt the need to be relieved of the burden of worrying whether I would be well enough, and the need to make sure that the law school had sufficient time to find coverage for my classes. It was a relief to finally communicate my decision, but that, of course, was complicated by the fact that I was our primary breadwinner, and how could we afford to be without my salary?

That problem was addressed by the second of my wonderfully empathetic bosses, the then dean of NYLS, Jim Simon, who immediately arranged for me to be on

\footnotetext{
${ }^{106}$ By this I mean not that I was manic, but that it felt so good to feel normal, that normal felt sublime.

${ }^{107}$ I was struck by the poet, Jane Kenyon's husband's distinction between the gray and black periods of her depression. Donald Hall, supra note [], at 162.
} 
paid leave. With that worry removed, I really was able to concentrate on getting better, one day at a time. And although when in the darkest moments of despair, I truly didn't believe I would ever be able to teach again, in more tempered moments, I was at least able to "have faith in the faith of others," a mantra I have invoked many times since (and recommended to others). And slowly, my moods evened out. Even before I evened out completely, when I felt "myself" I would participate in the life of the law school, other than teaching, including continuing to work in my office on the article I was still researching and writing. ${ }^{108}$ And I began to repopulate my life with people other than Doug, most of all with my friends and my family.

And then, gradually, I returned to normality, and resumed full time teaching in the fall of 1986. My belief in myself and my abilities was restored, subject only to the familiar ebbs and flows of self-doubt and self-confidence that had marked my whole life. I finished the first article and, monster though it was, I had tamed it sufficiently to succeed in placing it with a fairly solid law review. I finished a second article. I had a respectable draft of a third. I applied for tenure in my eleventh semester at NYLS, in the fall of 1988.

Every law professor who has gone through the tenure process knows how anxiety-producing the tenure process is, even if one has every reason for confidence. Facing judgment on your worth, having colleagues hold in their hands your professional future, can't help but unnerve even the most self-assured individual. And I wasn't the most self-assured individual. Nonetheless, I had confidence that it would all work out. Having been a high-achiever my whole life, academically and vocationally, objectively I knew that this should be no exception. I looked for, and found, signs to confirm that assumption from my colleagues. I submitted my tenure package in the fall and, in December 1988, learned that I was pregnant. ${ }^{109}$

\footnotetext{
${ }^{108}$ See supra note [], at

${ }^{109}$ Doug and I were thrilled - and terrified. We were hoping to conceive, but when the news actually arrived--we were on vacation in Tortola when the pregnancy stick revealed its magic color-we were both in a state of shock. Josh was almost fourteen. Were we really prepared to start all over again, to sign up for at least ten more years of always having to insure some responsible adult, usually one of us, would be with our child?
} 
I waited expectantly in my office on February $17^{\text {th }}$ for the good news, the day the tenure committee was deliberating on my application. The news that came, however, in the form of the chair of the committee, was devastating. The committee had voted against recommending me for tenure. My scholarship, he said, didn't measure up. My second article-which critiqued the Supreme Court's jurisprudence on the award of attorneys' fees for successful administrative resolution of federal discrimination claims ${ }^{110}$ - was more like a first rate student note than the kind of theoretical scholarship demanded by the faculty's standards.

This isn't the place for me to rehash all of my resentments about the whole unhappy process. ${ }^{111}$ But what's most important is that I didn't give up; I didn't accept their negative judgment of my worth. I interviewed each and every member of the Committee and asked them why they voted as they did. I wrote an answer to all of the expressed concerns and asked the Committee to reconsider its decision. They declined. I appealed to the faculty, who by a bare majority rejected the Committee's recommendation. ${ }^{112}$ The Dean rejected the faculty's vote because it was so close. Colleagues and students championed my cause. And, when none of those steps proved sufficient to reverse the decision, I asked the dean to extend my terminal year, to give me until 1991 to find another position. He readily agreed.

I loved teaching; by this time, I even enjoyed writing the required scholarship. I was determined to do everything in my power to find another teaching position, even with a virtual scarlet "TD" emblazoned on my forehead.

Despite this, my first ever professional setback, despite the constant anxiety about my vocational future, I did not fall apart. I did not sink into another depression,

This was further complicated by news that my ob/gyn was trying to reach me. I had had a routine PAP smear shortly before we left for Tortola; the results came back showing dysplasia, again. See supra note []. This was pretty terrifying - what would it mean in terms of the pregnancy? Ultimately, to my great relief, the oncologist - happily not the same one as in August 1985! - determined that there was no dysplasia and the abnormal PAP was due to the pregnancy.

${ }^{110}$ Evening the Odds: The Case for Attorneys' Fee Awards for Administrative Resolution of Title VI and Title VII Disputes, 67 N.C.L. REV. 379 (1989).

${ }^{111}$ There were an extraordinary number of candidates who had applied for tenure that year-eight of us. Five received tenure, three of us didn't. The three of us who didn't included me, a clinician, and the only African-American.

${ }^{112}$ At least that's my recollection; I can't attest to its accuracy. 
at least not then. In fact, as with my first, my second pregnancy enhanced my sense of wellbeing and, when in April, the amniocentesis revealed that my baby was a girl, I experienced pure joy, the first happiness I had felt since the day of the tenure denial.

I knew, of course, that I was at risk for experiencing postpartum depression, ${ }^{113}$ and did what I could to prepare for that possibility. I consulted with Patrick McGrath, the psychopharmacologist with whom Dr. Fischel consulted. We agreed that should it become necessary to resume antidepressants (which I had slowly phased off of after the last episode), I would cease breastfeeding. I interviewed a local pediatrician, told him about my history with depression to get a sense of how well he would be able to work with me should it happen again. He failed my test. And before I had the chance to meet with other pediatricians, Lucinda Sarah Block (Lucy) entered the world on August 1, 1989.

As when I gave birth to Josh, my labor and delivery were as smooth as my pregnancy had been. Doug, Josh, and I reveled in our new baby girl. Josh was thrilled to have a baby sister, and the three of us often argued over who would have the privilege of changing her tiny diapers. ${ }^{114}$

All was well through the summer, although at about three weeks Lucy developed colic, or whatever it is that makes waking babies cry for no apparent reason. Josh had been the same way, although in his case, I always assumed it was my depression that was the cause.

We found a nearby mother of a six-month-old to take Lucy for several hours a day so I could work on my third article and start the job search. ${ }^{115}$ Working at home was challenging. My desk was in the living room, facing a wall. The space was cluttered, with the possessions of four people-including one heavily-equipped baby-packed into a two-bedroom apartment. I had never worked well in a cluttered environment. Lucy's port-a-crib stood to my left. Even without her in it, I often found it hard to concentrate.

\footnotetext{
113 See supra, note [] and accompanying test.

${ }^{114}$ I joked that the ratio of three "adults" (Josh was 14 when she was born) to one infant was perfect, and urged others to put fourteen years or so between their children's births.

${ }^{115}$ The understanding with Jim Simon was that I would try to find a position for the fall of 1990, but if I didn't succeed, I could continue teaching at NYLS during the 1990-91 academic year. See supra note [].
} 
I worried about the future. But I held it together. That is, until I learned in October that Doug's sister, Karen, with whom I had always been close, was tumbling into what would turn out to be her first episode of clinical depression.

The news unraveled my precarious mental health. It had been three and a half years since my last episode, and about three months since Lucy's birth.

Did this still qualify as postpartum depression? Did it really matter? I ceased breastfeeding, resumed antidepressants and frequent visits with Fischel, and plummeted back into the familiar pattern of extreme anxiety, not sleeping, followed by flat affect, disconnection from everyone but Doug-including my new baby-and confident only in my belief that all was hopeless. And, also as before, I soon cycled between periods of gloom and periods of relative normalcy. When I felt better, I sent off expressions of interest to local law schools. But when Touro called sometime in January, inviting me to interview, I was terrified. I begged off, stating that I had decided it would be best if I remained at NYLS for the following year, using being a mother (again) as an excuse for not making any major changes professionally at that time. I still had to face the spring semester. Once again, the decision of if and when to notify the dean about my status weighed heavily. Ultimately, it was decided that a colleague would cover for me if I wasn't able to come back at the beginning of the term, in anticipation that I would soon be able to take over. ${ }^{116}$ This arrangement produced tremendous anxiety but somehow, after a few false starts, about three weeks into the 1990 spring term, I went back. It wasn't easy at first, but as time went on, as had happened during prior episodes, my mood swings evened out and I returned to me. ${ }^{117}$

${ }^{116}$ As I recall, I would only be teaching one section of one course, Administrative Law. I am extremely grateful to Jethro Leiberman for covering my course in my absence.

${ }_{117}$ This time, I didn't completely phase off of Imipramine after I recovered, but did phase down to a "maintenance" dose. See, e.g. Patient Information About Antidepressant Medication, supra note []: [A]fter a first depressive episode, it might make sense for the patient to gradually come off medication. However, after a second and certainly after a third episode, most clinicians will have a patient remain on a maintenance dosage of the medication for an extended period of years, if not permanently.

See also Commentary on the American College of Physicians' Clinical Practice Guidelines for Using Second-Generation Antidepressants to Treat Depressive Disorders, supra note []. Recommendation 4: "... [t] $]$ he goal of maintenance treatment is to decrease the likelihood of a next episode." 
In the fall, I resumed the job search with renewed vigor. I expanded my search geographically, and had second interviews at several schools, including Touro. I called upon all my influential friends in legal education to "campaign" for me. And, happily, despite everything, ${ }^{118}$ I succeeded in getting an offer. By then I was really impressed with many members of the Touro faculty I had met. I was thrilled. Against the odds, I was still in the game.

I recall vividly the beginning of the first faculty meeting in August 1991. As faculty warmly greeted each other, they immediately asked after one another's children. Children, and their accomplishments over the summer, seemed to be the most popular topic of conversation--what a contrast! I soon learned that this was an environment in which I could relax and be me. I no longer had to put on any pretenses. Many members of the faculty, whose backgrounds were mostly in civil and criminal poverty law, were impressed by my scholarship, which at that point had dealt with procedural obstacles to enforcement of non-discrimination obligations. I had every reason to relax about earning tenure in due course.

Meanwhile, I was coping with my mother's descent into dementia. We first noticed something was up not long after Lucy was born, when my mother mistook Lucy's Pamper for pajamas. My parents were both still living in the house on Long Island where I grew up, about a twenty-five minute drive from school. Comparatively little was known about Alzheimer's disease ${ }^{119}$ at that time, and there wasn't much in the way of support systems. I consulted my mother's gynecologist, with whom she had had a

\footnotetext{
${ }^{118}$ The chair of the Appointments Committee for the 1989-90 academic year, Barbara Swartz, had called me in the midst of my depressive episode. I was in no condition to interview for any position. I managed to get through a phone conversation — not without a huge amount of anxiety - and told her that, given the arrival of new baby, I had decided to remain at New York Law School for an additional year, and hoped Touro would consider me for the following year. Years later, I learned from Barbara, who subsequently became a dear friend and colleague, that she had been quite put off by my response. I was glad to finally be able to tell her the real reason for deflecting the invitation to interview. In addition, when I did obtain an interview the following year, and the appointments committee recommended that I receive an offer, then Dean Howard Glickstein had been quite resistant. Under his tenure, Touro had had several Dean's unhappy experiences with former NYLS faculty, and was understandably reluctant to repeat that experience. I am fairly confident that Howard is glad that his objections failed to carry the day. He, too, especially in his most recent role as dean emeritus and faculty member, has become a dear friend and colleague.

${ }^{119}$ Her dementia was only definitively diagnosed as Alzheimer's by autopsy after her death in 1994.
} 
decades-long relationship, who pooh-poohed my concerns, chalking my mother's bizarre actions up to the natural decline of advancing age. ${ }^{120} \mathrm{I}$ then arranged for her to see a gerontologist. My father was not coping well at all with this personal tragedy, and was more angry than empathetic at my mother's lapses, and what this meant for their future. As my sister lived on the other coast, it mostly fell to me to investigate options and make contacts. As her condition deteriorated, we arranged for 24/7 home care, provided by a series of underpaid agency aides.

In February 1993, my father had a major coronary incident, and was rushed to Winthrop hospital in Mineola. That began a series of consultations with cardiologists and other specialists as to how best to treat him. The decision was finally made for him to undergo a bypass, with the known risk that at his age, there was a substantial risk that he either wouldn't survive it, or, if he did, that he might suffer a major stroke in the process. While he was in the hospital, the aides were with my mother at home.

The evening before my father's scheduled surgery, while I was teaching class, I was interrupted by someone from the dean's office and told to call my parents' home immediately. My mother had collapsed at the kitchen table. By the end of that evening, I had two parents in Winthrop hospital. I also had a three-year-old at home. And a husband. And a son in his senior year of high school, with all that entails. Needless to say, I also had fulltime obligations at the law school, with preparing for and teaching my classes not the least among them. I was pretty frantic. I called Doug from the emergency waiting room, and he immediately called my sister in California. We needed her help. I needed her to come. Her response was that she was just too busy with work. Thankfully, I had Doug for emotional support, and to be there for Lucy. But I still was the one who had to make the decisions and deal with the medical and logistical fallout of my parents' decline. And it only got worse.

My father survived the surgery, but over time, it became clear there was some cognitive loss. Both of my parents returned home, ${ }^{121}$ but now they both needed care.

\footnotetext{
${ }^{120}$ My mother was 76 at the time.

${ }^{121}$ As I recall, my mother was released from the hospital after only a few days of tests and observations; the cause of her collapse was never determined.
} 
One day, in the shower, my father had a massive rectal bleed, and was rushed back to the hospital. I was running back and forth between the city, their home, the hospital, and school. It was overwhelming. I had no time for my children, my husband, my students or myself. I worried about my father's care, about how we could keep from depleting his resources. I worried about his law practice; he had no partners. Who was responsible to his clients? Was I? Could I lose my license to practice if their cases were neglected? What was going to happen to my father? How would we care for him? Doug and I had scheduled a vacation to Spain and Portugal for June. What if he was ready for discharge while we were away? Could the hospital just discharge him? Where would he go?

My anxiety grew and grew, about the real and the imagined. I feared I couldn't hold on much longer.

I somehow got through the semester, barely. I met with a lawyer who practiced elder law. She was the wife of someone I knew, and I just wanted some advice. Rather than feeling reassured afterwards, I felt more anxious. She treated me like I was just any client; I expected and wanted to be treated like a friend. Unrealistically (in retrospect), I wanted her to take care of me and my father. Her bill arrived; it was for several hundred dollars. I was outraged.

I can no longer recall exactly when I let go, when I gave up. But I did. The onset of my depressions have been like hanging on to a window sill, hanging on, hanging on, increasingly anxious, unable to sleep, no appetite, no joy, overwhelming self-criticism, anxiety, keep hanging on, keep hanging on, until I feel I can't hang on any longer, and then I let go. And once I let go, gravity takes over, and there's no going back. ${ }^{122}$

Doug called my sister. Now she had to come and deal with my parents. ${ }^{123}$ I no longer could, and he had me and Lucy to take care for.

\footnotetext{
${ }^{122}$ See Solomon, supra note [], at 27: "Depressives use the phrase "over the edge" all the time to delineate the passage from pain to madness. This very physical description frequently entails falling 'into the abyss'...."

${ }^{123}$ I recall she had already come once, for a short visit, to see my father at some point after his surgery. The chronology, however, escapes me.
} 
As I mentioned, this was Josh's last year of high school. It was excruciating attending his graduation, and the dinner that followed, and I was overwhelmed with guilt for doing this to him. He went on a trip that summer to England with the school's chorus; I saw him off, but knew none of the details and had no contact with him while he was away. I feared I would never see him again. As with every depressive episode, my world kept shrinking, even shutting out my children. ${ }^{124}$

Doug thought it would help if we went on our scheduled vacation; most of it had already been paid for. I was terrified of going away, and, as I recall, Fischel supported my decision. I was in no condition to travel. We cancelled our vacation. Doug's sister, Karen, had already agreed to take Lucy for the two weeks we were to have been gone, and we decided it made sense for Lucy to go to Karen's to reduce the stress we both were under. I recall feeling relief at dinner out that night after dropping Lucy off in Connecticut. But by the next morning, the anxiety had returned in full force. Doug had hoped we could at least go out to the place we rented in Sagaponack, and have a sort of vacation, but I was terrified of being around other people. ${ }^{125}$ So we remained in the hot city, with little relief for him or me, and I hadn't really improved any by the time Lucy returned. Somehow we struggled through July. Lucy's August $1^{\text {st }}$ birthday was approaching; she would be four. I remember agonizing over what to do about that; just thinking of a present, let alone the party we had had for her in one or the other of our parents' backyards each year since she was born, seemed impossible. We did have a party, and I managed to be there, but being around other people when I felt so strange, so not myself-even though they were family and friends-was so, so hard. ${ }^{126}$

And, of course, I was again faced with what to do about teaching in the fall. The what and when of the decision, the indecision, produced tremendous anxiety. As always, even in the depths of my depression, I needed to be responsible. I didn't want

\footnotetext{
${ }^{124}$ See supra, text at note [].

${ }^{125}$ What we had was a room in what had once been a boarding house. The other occupants were mostly dear friends of longstanding — we had been renting there for more than ten years — but that made little difference in my mind.

${ }^{126}$ Another memory from the party that punches me in the gut whenever I go there, was handing Lucy an ordinary beach ball - something we had purchased for every child who came to the party — and her thanking me so politely even though she must have been thinking "Is this all? On my birthday?" Or at least so I projected. Lucy claims to have no memory of anything being wrong with me at that time.
} 
to leave the decision to the last minute, leaving the school in the difficult position of finding eleventh hour coverage, especially not for a first year course,. I had taught at Touro for two years. I did not yet have tenure. ${ }^{127}$ At some point, I informed the dean that I would not be able to teach in the fall. While that provided some relief, I was also sure I would never be awarded tenure. And we had to cope with receiving only half my salary for the year. ${ }^{128}$

The problem of care for my mother and father still remained. My sister came east and checked out nursing homes, choosing a public facility in Uniondale on Long Island for my father. He was transferred there from the hospital in, I believe, August. Shortly thereafter, we decided that it was infeasible for my mother to remain in her home. She, too, was admitted to the same facility, not with my father, but on a ward for people with dementia. It was time to sell their home, the house in which I had lived from age five until I left home. Talk about stresses!

Despite all this, the depression inevitably lifted, and I was able to handle what needed to be handled, not without pain, not without anxiety, but I was functioning again. When the anxiety hit, frequently in the morning, I took a small amount of Ativan $^{\text {TM }}{ }^{129}$ which took off the edge. Shortly after Josh left for college, we were offered a larger apartment in our complex, and moved on October $1^{\text {st }}$. Despite the stress that moving had always represented, I did not fall apart. I remember going to a Halloween party at Lucy's nursery school in October, feeling anxious, spacey. Not feeling myself, but nonetheless knowing that I was on the road to recovery, that I would recover, once again. That I would be ready to return to teaching in January. That yes, perhaps I would achieve tenure someday.

And I did. I was awarded tenure and promotion to full professor in 1995. As far as I could ascertain, my mental health was never a consideration, one way or the other.

\footnotetext{
${ }^{127}$ I had, in fact, applied for an early tenure decision in October of 1992, after only one year at Touro. Some time in May 1993, while my mental health was already unraveling over the health care of my parents, the Promotion \& Tenure Committee deferred my application as premature. Although I don't recall this as profoundly unsettling, I'm sure it didn't help my confidence about my professional future.

${ }^{128}$ I was put on unpaid leave. However, my anticipated salary for the spring semester was prorated over the year, and, luckily, I was able to maintain my health insurance coverage. I also applied for and obtained short-term disability benefits - a negligible sum of money, but it helped.

${ }^{129}$ The generic is lorazepam, an anti-anxiety medication similar to Valium ${ }^{\mathrm{TM}}$ or Xanax ${ }^{\mathrm{TM}}$.
} 
After each of the prior depressive episodes, I had either phased off antidepressants completely, or, as was the case between the 1989/1990 and the 1993 episode, had phased down to a "maintenance" dose. Clearly, that hadn't worked sufficiently well. This time, in consultation with both Fischel and McGrath, the psychopharmacologist, it was determined that I would stay on the therapeutic dosage of my antidepressant, imipramine, the dosage at which I had recovered.

And it worked-for a long, long time. Life after tenure was all that I had assumed it would be. I felt a freedom as a scholar to pursue whatever interested me, and what interested me was exploring the psychological aspects of lawyering. I hooked up with the Therapeutic Jurisprudence movement, and its founders, David Wexler and Bruce Winick, became both mentors and friends. In 1999, the Clinical Law Review published my first major piece in this, for me, new field. ${ }^{130}$ It was a very proud accomplishment. I wrote an essay about the importance of emotional intelligence to good lawyering, and the need to teach about it in law school, using analogies from literature, plays, and popular culture, harking back to my pre-law interests in literature and creative writing. ${ }^{131}$ Out of this came an invitation to submit a book proposal to the American Psychological Association ${ }^{132}$ about the skills such as psychologicalmindedness, emotional intelligence, and cross-cultural competence that lawyers need to practice law.

I spent two summers working on that book proposal. Although I was thrilled to have been solicited and to accept the offer, it became clear that what I had in mind did not comport with the ideas of the editor of the series. I wrote draft after draft of the proposal, got feedback from both Bruce Winick and the editor who had solicited me, rewrote, and repeated the process over and over. It was the source of significant stress. There were many times I would sit at my computer, staring at the screen, not being able to string an English sentence together. Other times, the words would flow effortlessly.

\footnotetext{
${ }^{130}$ Love, Hate and Other Emotional Interference in the Lawyer/Client Relationship, 6 CLINICAL L. REV. 259 (1999).

${ }^{131}$ Emotional Intelligence and Legal Education, 5 J. PSYCHOL. PUB. POL'Y \& L. 1173 (1999).

${ }^{132}$ Specifically for its series on Law \& Public Policy: Psychology \& the Social Sciences.
} 
Nonetheless, even when I was satisfied with what I had produced, it didn't meet the editor's expectations. It was an undertaking that seemed to paralyze me.

This feeling, off and on, of not being able to formulate a written sentence, followed by periods of confidence in my ideas, my writing, and a sense of "flow,"133 appeared and persisted in other arenas of my professional life. It struck me as a manifestation of the duality about my abilities that had always plagued me. I was incompetent and had already used up every new and original thought I had ever had or would ever have in the writing I had already produced. No-wait-there's an original idea again-and it's a good one! Maybe I do have more to contribute. Off and on. Time after time.

During this period, around the year 2000, something else of significance entered my life: the Landmark Forum. Landmark is an organization that provides a transformative education, designed to enable participants to achieve breakthroughs in any and all arenas of their lives. ${ }^{134}$ At the time I took the Forum, it was promoted as a "curriculum for living." ${ }^{135}$ The other members of my family, including my then 10-yearold daughter, had already done the Forum, and the results had been really impressive. ${ }^{136}$ My son, Josh, was the first to do the Forum and I saw him make as much progress in self-awareness and self-actualization in the course of a long weekend as I had made in years of psychoanalytically-oriented therapy. I saw similarly remarkable results when my husband ultimately succumbed to Josh's not-so-subtle pressure. In fact, I had actively encouraged him to try the Forum. But I just hadn't felt that I needed it. I had spent many years exploring my psyche, dealing with the roots of my unhappiness, and had come to a place where, when I wasn't depressed, I was, for the most part, incredibly happy with my life, both professionally and personally.

\footnotetext{
133 "Flow" is the state of being so fulfilled by, so engrossed in, an activity that one is not conscious of the passing of time. See generally Mihaly Csikszentminalyi, Flow: The Psychology Of OPTIMAL EXPERIENCE (P.S.) (2008).

${ }^{134} \mathrm{http}: / /$ www.landmarkeducation.com/landmark_forum_educational_methodology.jsp (last visited $5 / 20 / 10)$

${ }_{135} \mathrm{http}: / / \mathrm{www}$. landmarkcurriculumforliving.com/ (last visted 5/20/10).

136 http://www.landmarkeducation.com/landmark_forum_for_young_people.jsp (last visted 5/20/10).
} 
It actually was at a time I was experiencing deep wellbeing that I decided to do the Forum, just after I was solicited to submit the book proposal. My son insisted that as rich as my life then was, it would be even richer if I had the tools the Forum provided. I decided to take the plunge, and see what it had to offer.

And what it had to offer was truly amazing. A combination of philosophy, psychology, spirituality, and yet not exactly any of these, the Forum cut through the crap of the defenses that we humans create, generally unconsciously, that keep us from having the life we want. I learned to appreciate the distinction between what happens and the story we make up about what happens. For example, if my husband doesn't hear what I say, then I make that mean something, often that he just doesn't care about me. When, in fact, it might be that he was distracted by something else-or his hearing is going! The "rackets" we run on other people are generally negative judgments that make us feel superior, or victimized, or justified, and thus serve a need we have to feel so. However, these "rackets" have a cost, and that cost is usually in intimacy and joyfulness in the relationship. If I can love my husband "for who he is and who he is not," then I won't be constantly criticizing him whenever he disappoints me. Another critical lesson of the Forum - and the advanced courses and seminars that followed-is learning to put the past in the past. So I learned to forgive myself quickly when I make mistakes. I take responsibility for those mistakes. I start over, knowing that I can't go back.

Now, I don't in any way claim to be the perfect practitioner of the Landmark arts. And I haven't taken a course in several years, as my resentment over the evangelical nature of the organization and its emphasis on enrolling new recruits has outweighed the additional benefits I felt I was receiving. My tendency to be judgmental and harshly critical rears its ugly head more often than I would like to admit. But frequently, persistently, the concepts I learned during my time at Landmark have informed my life and my teaching, and have enhanced my joy in the life that I have.

At some point I used what I had learned in Landmark to make a very healthy decision. I decided that I was not interested in writing the book that APA Press wanted 
me to write, that it would continue to be a negative stressor, and would diminish, rather than enhance, my wellbeing. So I informed Bruce Winick and the series editor of this decision, and immediately felt lighter.

These years were also marked by numerous life stresses. My mother passed away from pneumonia in the acute stages of Alzheimer's in February of 1994. Although everyone expected that my grief would seize me at some point, it never did. I had mourned her loss over and over while she was still alive, as her mind left her body, would occasionally revisit, and then depart again. In 1995, I was diagnosed with cervical cancer, found during a routine Pap smear that, since my dysplasia in 1985, I had had performed twice a year. Going from a series of completely normal PAPs to cancer was quite unusual and alarming, and I was most definitely scared. However, the anxiety never overwhelmed me the way it had during my depressive episodes. I tenaciously sought out the gynecological oncologist who had seen me during my second dysplasia scare when I was pregnant with Lucy. ${ }^{137}$ She had since moved on in her career, and it was intensely challenging to get access to her, but I was not to be dissuaded. ${ }^{138}$ । succeeded in contacting her, despite efforts of her staff to keep that from happening, and she performed a successful cone biopsy which excised the nasty stuff and left me intact. And I said often, and still very much believe, that dealing with cancer was so much easier than dealing with depression, because I had a mind to wrap around the problem.

Other events and stresses - a 1996 crisis in my marriage; my father's 1998 death; my having to care for my deaf/blind uncle and his deaf wife from 1998 until the latter's death in 2002; September $11^{\text {th }}, 2001$; my mother-in-law's untimely death in February 2002; three months later my father-in-law's taking up with his secretary from forty years earlier; ${ }^{139}$ the planning and execution of a highly successful Continuing Legal Education

\footnotetext{
${ }^{137}$ See supra note [].

${ }^{138}$ Given the horrid experience I had had with the gynecological oncologist who performed my surgery in August 1985, see supra note [], I was determined to not risk a similar experience, and desperately wanted to have the doctor whom I trusted as a clinician and a human being to take care of me this time.

${ }^{139}$ For the full story, see 51 Birch Street (2006), my husband's personal documentary about what he discovered about his parents' lives after his mother died. http://www.amazon.com/s/ref=nb_ss?url=searchalias\%3Daps\&field-keywords=51+Birch+Street.
} 
(CLE) conference at Touro in April 2003 entitled Lawyering and its Discontents:

Reclaiming Meaning in the Practice of Law-none of these precipitated a mental health breakdown. I finally felt confident that staying on imipramine at a therapeutic dose, and checking in with Fischel twice a year, was sufficient to keep me on the sane side of existence.

One day when I was walking to my exercise class, I realized I knew what book I did want to write-or rather edit. I was thinking about my April 2003 conference. I knew so many amazing people who had written so many amazing things, all relating to the practice of law as a healing profession. Many of them were connected to Therapeutic Jurisprudence, whose writings I had read or whose presentations I had attended at various conferences. Others were clinicians whose writings I had come across while researching the essays and articles I continued to write in this area. I wanted to bring these voices together in one anthology. I shared my idea with Bruce Winick and David Wexler, and they were tremendously enthusiastic. So I worked up a book proposal in the summer of 2004 and, with no small help from David Wexler, had a contract almost immediately with Carolina Academic Press for The Affective Assistance of Counsel: Practicing Law as a Healing Profession, with a promised completion date of August 2006. All but one of the authors, scholars and practitioners I invited to contribute original or previously published work to the anthology said yes. This was a remarkable group of caring and responsible people doing great things to enhance the therapeutic practice of law. This project became my passion, my joy, and occupied the bulk of my time for the following two years.

However, in the spring of 2006, I began to notice some problems with my teaching. I had enjoyed a sabbatical to work on the book during the fall 2005 semester. In the spring, I was assigned to take over the evening section of Civil Procedure. It was in the Moot Court Room of our old building in Huntington, Long Island, a long room of twelve rows with ten seats in each. ${ }^{140}$ I had taught in the same room many previous semesters and although it was hardly my favorite, it had never presented any particular

\footnotetext{
${ }^{140}$ Touro Law Center moved to a new building in Central Islip in January 2007. See infra, text at note [].
} 
problems. This time, however, although I enjoyed this feisty group of second semester evening students, I found that I often struggled to decode and respond to many of the questions they posed to me, a problem I did not recall having previously experienced. I just didn't seem able to process the questions or their answers on my feet, certainly a handicap for a law professor. I was fairly certain that I was losing a certain cognitive ability with age. This was rather disturbing. However, as my work on the book was proceeding incredibly well, I didn't doubt my overall mental capacity. The fear, however, that my mother's Alzheimer genes were lying in wait for me, was never far away.

That summer was spent largely doing the final editing of all of the book's chapters. Stephanie Adduci, my terrific research assistant, and I painstakingly reviewed multiple drafts, cross-referencing, rationalizing citations and footnotes, and all the other work that goes into producing what turned out to be a 530 page book. It was hard work, but not particularly stressful, and, on schedule in August, before I returned to school, I sent the manuscript off to the publisher, assuming the lion's share of the work was behind me. I was wrong.

I knew I was facing a particularly challenging, but nonetheless extremely exciting, teaching semester. I would be teaching the seminar for our Civil Externship program for the first time. I had requested to teach this seminar so that I could help these rising graduates, to a greater degree than likely any other courses at Touro, focus on how to create a life in the law that would be congruent with their core values, that would serve their clients as human beings rather than cases, and sustain them as practitioners throughout their professional lives. ${ }^{141}$

\footnotetext{
${ }^{141}$ In the spring of 2005, I had taught a seminar entitled Selected Topics in Professional Responsibility: Lawyering as a Happy, Healthy, Healing and Ethical Profession, the name being a take-off on the incredibly thoughtful and powerful article by Patrick Schiltz, On Being a Happy, Healthy, and Ethical Member of an Unhappy, Unhealthy, and Unethical Profession, 52 VAND. L. REV. 871 (1999). The four students and I in the seminar had a terrific experience. However, when I offered it again in the spring of 2006, it was cancelled for zero enrollment! I decided, after I picked my ego up off the floor, that the solution was to offer the course in context, attached to the highly popular civil externship clinic. I have continued to teach that seminar each fall, with tremendous satisfaction. See Mary Jo Eyster \& Marjorie A. Silver, The Accidental Clinician and the Experienced Director: A Conversation on the Value of Externships (working draft on file with authors).
} 
In addition, I had completely revamped my Civil Procedure course. Thanks to the faculty's endorsement of a Curriculum Committee proposal I had proposed, the course was now expanded to include a substantial component on alternatives to litigation, and renamed Civil Dispute Resolution and Procedure. My colleagues and I all agreed as well, at least for the first year, to assign A Civil Action, ${ }^{142}$ A Documentary Companion to A Civil Action, ${ }^{143}$ and to use a problem-based approach to the course. I, alone among us, had decided to junk the casebook altogether, substituting an excellent Civil Procedure hornbook, ${ }^{144}$ as well as a text which follows a hypothetical age- discrimination in employment case from the initial client interview through the entire litigation process. ${ }^{145}$ I was very excited about using this contextual approach, but it obviously involved a tremendous amount of new preparation. And when, due to a shortage of faculty, the dean asked whether I would be willing to take on an additional section of the course for the year, I agreed. The opportunity to present two-thirds of the full-time entering class with what I believed was an exciting, innovative, and preferable approach to teaching students about dispute resolution and lawyering as creative problemsolving, outweighed the burden of five additional credits and sixty-five additional students over the course of the year. I had once before taken on two Procedure sections plus Professional Responsibility. I knew it would be a very challenging semester, but I didn't doubt my ability to carry it off. At least initially I didn't doubt it.

The work remaining on the book—the "back" and "front" matter, as well as designing the cover and soliciting testimonial quotes-proved to be far more timeconsuming than I had anticipated. Weekends were spent reading and providing feedback on my seminar students' journals, all of which I endeavored to complete before our Monday class. I struggled to keep ahead of my first year students, to prepare new "preparation questions," which I had been giving to students along with reading

\footnotetext{
${ }^{142}$ JONATHAN HARR, A CiVIL ACTION (1995).

${ }^{143}$ Lewis A. Grossman \& Robert G. VAughn, A Documentary COMPanion to A Civil Action $\left(3^{\text {rd }}\right.$ ed., 2006)

${ }^{144}$ Richard D. Freer, InTRoduction to Civil Procedure (2006).

${ }^{145}$ Michael Allen \& Michael Finch, An Illustrated Guide to Civil Procedure (2006). For a complete description of my course, see http://www.thecompletelawyer.com/legal-research-surveys/460460.html.
} 
assignments for years to help focus their study. Students were understandably frustrated to too often receive questions the night before the class for which they were due. I had intended to assign them two for-credit writing assignments over the course of the semester, in addition to the final exam, but reading and commenting on the first paper had taken so much time, given two sections and all the other demands on my time, that I made a "mid-course" correction and decided that I would assign only one. That meant that what students originally thought would count for $10 \%$ of their grade, a product submitted when they had had only a few weeks of law school under their belts, now counted for $20 \%$. Many students expressed their dissatisfaction, but there just weren't sufficient hours in the day (or night) for me to handle all I needed to do.

The semester was also complicated by the law school's plans to move to our new state-of-the art facility in Central Islip. The move was to have occurred before the commencement of the semester, and we had pretty much packed up our offices in anticipation the preceding May. But as is so often the case, the building was not ready in time, and we returned to our now rather chaotic old offices in August, not knowing when we would move. The date kept getting postponed, so we continued to live in a state of limbo, with students, faculty and staff all frustrated by the uncertainty. It was a time of low morale. Moves had never been my strong point ${ }^{146}$-especially the chaos created by packing and unpacking - and with everything else going on, this just added to my stress level.

I was intent on getting everything finished for the book by Thanksgiving so that it could be out in time for the annual meeting of the Association of American Law Schools in January, an important showcase for new publications. In addition, an extremely happy event had occurred the previous June: the birth of my first grandchild, Joshua and Margaret's son, David. ${ }^{147}$ I was committed to finding time each week to spend with David and give Margaret, who was on leave for the year, a welcome break. It was also

\footnotetext{
${ }^{146}$ See supra text, at note [].

147 Josh had married his college sweetheart, Margaret, in October 2001, a truly happy occasion following the world-shocking events of the previous September $11^{\text {th }}$.
} 
my daughter Lucy's, senior year of high school, with all that that entailed. ${ }^{148}$ And, were all that not enough, I was planning a sort of "coming out party," for my book, a/k/a CLE conference entitled Law as a Healing Profession, largely on my own, ${ }^{149}$ and involving the contributors to my book and numerous others - scheduled to be held at Touro in April 2007. As I write this, it seems ludicrous that I ever thought there were enough hours in the day, week, semester to accomplish all that I had taken on.

As the semester progressed, my anxiety level grew. I felt less and less competent and increasingly worried about the decline of my cognitive abilities. It was becoming more and more difficult to keep all the balls in the air. ${ }^{150}$

Months before, I had agreed to do an in-house CLE for the Center for Court Innovation ("CCIC") on the Comprehensive Law Movement and new trends in lawyering. It didn't seem like a big deal at the time I agreed to do it, and I had arranged for it to be in December after classes ended and before my first years took their final exam, when I would have the most time. I didn't even focus on it until November, and by then was swamped with last minute book details, especially the preparation of the index. I also still had a final exam to write, a task that has always required me to have some mental space to do well. I decided to do a meditation as part of the CLE, and invited one of my research assistants, $\mathrm{P}$, a graduating student with a regular meditation practice, to teach the CLE with me, never thinking that this was something I should first run by the CCIC. It turned out to be a problem, and although P was allowed to co-teach the course with me, meditation was to be optional, and not part of the two hours of CLE credit.

I didn't have the time I needed to do a sufficiently competent job preparing for this, and I had great difficulty focusing on what to include, what to exclude. I was

\footnotetext{
${ }^{148}$ Although there were numerous "events" surrounding this year, Lucy was proactive in taking care of her college applications. Accepted to Pomona College in Claremont, California on early admission, that potential stress was minimized.

${ }^{149}$ At the time of the 2003 conference, see supra, text at note [], I had partnered with our dynamic, committed CLE director, also a lawyer committed to humanistic approaches to lawyering, Lynne Cahalan. Lynne had since left the Law Center, and the dean had decided not to replace her with another lawyer. I was working, for the most part, with one person in our development office, but she was torn in multiple directions, so I had far less support in organizing the conference than I had had for the prior one.

${ }^{150}$ The metaphor of a juggler is a frequent refrain in my self-understanding, and the worry I would experience about "dropping a ball;" if I did so, terrible things would happen.
} 
extremely nervous about it and, in my judgment, it was pretty much a bomb. P was incredibly-and understandably-nervous, and her presentation was stilted and unpolished. ${ }^{151}$ I was fairly certain I had disappointed the CCIC attorney who had asked me to do the training. Just one more thing that led to my disappointment in myself and my abilities.

And then my exam. I had represented to my students that questions about a certain subject covered quickly towards the end of the semester would not be on the exam. Not until it was too late, did I realize that I had included two short questions on that subject. I was horrified. I had betrayed my students. How could I face them? What should I do about it?

I somehow managed to get through the proctoring of my exam. No student called me on my broken promise, but that didn't seem to help my state of mind. By the next day, my anxiety was out of control. It had been thirteen and a half years since my last breakdown.

Thus began my sixth and, as of now, last episode of depression. I had assumed that since I had been well for so long on a therapeutic dose of imipramine that I was pretty much safe from falling apart again. Obviously, I was mistaken. And if imipramine was my lifeline, what did this now mean ${ }^{152}$

Again, despite assurances from those closest to me that this episode, like the others, would pass, I was convinced that I was doomed. I was certain that anxiety and depression notwithstanding, the cognitive deficiencies I had been experiencing prior to my breakdown were permanent and likely progressive, and that I would never again be competent to teach law. And if I couldn't teach, how would we support ourselves, and the comfortable, albeit not extravagant, lifestyle, which we enjoyed? Rent on a house on the eastern end of Long Island and on our New York City Apartment. Lucy's college

\footnotetext{
${ }^{151}$ I believe it was only later that I learned that $\mathrm{P}$, too, suffered from debilitating anxiety, and I would later support her through her own depressive episode. Even had this not been the case, acting on the impulse to invite $\mathrm{P}$ to co-present with me, without having first discussed this with the CLE sponsors, demonstrated the lack of clarity in my thinking so characteristic of my escalating anxiety and depression.

${ }^{152}$ See SolOMON, supra note [], at 90, describing the extra horror he felt when he experienced a breakdown while on the medication that had previously seemed to prevent any. "[I]t was a breakdown and it had taken place while I was on medication, and I have never since then felt fully secure." Id.
} 
tuition. Health care. Doug assured me that if he needed to get a salaried job to support us, he could and would do so, ${ }^{153}$ but I was convinced that there was no way that he could command a salary that would meet our economic needs.

This was the first time Lucy had really experienced my depression, as she had only been a toddler during the last breakdown. I hated what I was doing to her, during this, her last year home before heading off to college (which of course I was convinced we now weren't going to be able to afford). I hated how despicably weak and pathetic I was.

As in 1993, vacation plans were pending. The three of us were to return to what would be our last sojourn to La Posada del Capitán LaFitte, a very special, very unpretentious place in the Yucatan, on what has come to be known (unfortunately) as the Mayan Riviera. This low key resort had been our family's favorite winter break destination for over a decade. The property on which it was situated had recently been sold to developers, and this was to be its last season. As in 1993, however, I couldn't imagine going. On the other hand, cancellation would be a huge disappointment to both Doug and Lucy. I recall a three-way session among Fischel, Doug and me, with Fischel suggesting to Doug that insisting that I go might jeopardize my wellbeing, and Doug insisting that nonetheless, we would be going. We went. And for those eight days, I pretty much clung to our cabana, never once going into the water. I remember it as a very dark time in a place that had always been my idea of paradise, sunshine and turquoise blue water. But we all survived it, and I returned to New York around New Years in no worse, if no better, shape than before.

Not that my mood and affect remained constant throughout this period, no more so than in previous episodes. I remember feeling rather hypomanic, ${ }^{154}$ and yet no less doomed, the first night we arrived there. Lucy and I cuddled up together and she asked questions and I tried to explain what the anxiety and depression were like, sharing some details that I now wish I had spared her. But it was if I had no filter, no

${ }^{153}$ As Doug was now making his own documentaries and struggling to get them funded, he had only a modest income from a handful of weddings he "shot" each year. I had been the primary breadwinner since the beginning of our relationship.

${ }^{154}$ See supra note [49] and accompanying text. 
superego to negotiate, no judgment about what was appropriate and what was inappropriate to share with my seventeen year-old daughter.

I did not attend the annual AALS meeting, at which my book would make its debut in the Exhibition Hall. All the pressure I put on myself to finish the book so that it would be ready for that occasion, and I missed it. Meanwhile, I had all those final exams to grade. With Doug acting as my intermediary, it was agreed that one of my colleagues would grade one set of exams, and I would do my best to grade the other. So, as in 1985-86, I graded when my depression and anxiety lifted sufficiently to allow me to do so. ${ }^{155}$ I managed to get through the one set, feeling terrible that one of my sections was being graded by someone who hadn't taught the course in the idiosyncratic way that I had.

Even in moments when I might not feel that my entire future was doomed, I was intensely anxious about the financial implications of having no salary for that semester preceding Lucy's commencement of college. I had once again decided that I could not face teaching during the spring 2007 semester; two of my colleagues took over my two sections of CDR\&P. ${ }^{156}$ The cost of our lifestyle had increased enormously since my last episode, with the rent for our second home and Lucy's private school tuition. We often didn't make it from paycheck to paycheck, and had to dip into savings.

Once again, I was blessed with the compassion of my employer. Our relatively new dean, Larry Raful, quickly assured Doug that my salary would continue for the spring semester, and that he would do anything he could to smooth the progress of my recovery. We postponed the conference I had been planning from April until November $2007 .^{157}$ I was welcome to return to the school and the life of the law school as soon and as frequently or infrequently as I felt able.

In mid-January, Doug and I had a consultation with Dr. McGrath, the psychopharmacologist. McGrath recommended that I phase off of imipramine and on to one of the (relatively) new SSRI antidepressant medications, Effexor XR ${ }^{\mathrm{TM}}$, which, he

\footnotetext{
${ }^{155}$ See supra text at note [].

${ }^{156}$ I remain extremely grateful to Lew Silverman and Fabio Arcila for having done so.

${ }^{157}$ See supra, text at notes [].
} 
said, worked in many of the same (mysterious) ways as imipramine. ${ }^{158} \mathrm{I}$, of course, had little faith that a change in medication would change my cognitive abilities. McGrath, however, assured me that he had absolutely no doubt that I would be able to teach again in the near future. But how could he know whether my cognitive abilities had declined independent of the depression? Did he really know something I couldn't see?

Perhaps not, but within a couple of weeks, happily, the shroud began to lift, and I could feel myself returning. Apparently, the change in medication was working. I moved from reading easy fiction ${ }^{159}$ to doing some actual work. I decided I would prepare a detailed syllabus for the second semester of CDR\&P, although, at best, I wouldn't be teaching it until spring 2008. It was a relatively unchallenging task, yet one that consumed a good amount of my waking hours. At this point, rather than wallowing in my misery and self-contempt, I was aware of taking positive steps towards healing. I resumed going to yoga classes, something I couldn't face during the breakdown period. And one night, while lying in bed, I had a breakthrough, an idea for my next research project which felt so exactly right. The irony is that it grew out of one of my moments of shame from the December CLE program. ${ }^{160}$ During the Q\&A, the social worker for the Brooklyn Mental Health Court program had asked me if I were suggesting that lawyers, like social workers, should have supervision ${ }^{161}$ with regards to their practice of psychological-mindedness and emotional competence. I responded, with no real reflection (at this point I just wanted to get out of there) that no, of course not; that would likely be impossible, even if ideal.

\footnotetext{
${ }^{158}$ See e.g. Effexor XR, How Does Effexor XR Work?, http://www.effexorxr.com/effexor-xr-treatment.aspx (last visited Oct. 5, 2009) (explaining that Effexor XR works by affecting "the levels of two naturally occurring chemicals in the brain - serotonin and norepinephrine," and that "[i]t is believed that correcting an imbalance of these two chemicals may help relieve symptoms" of depression and three other anxiety disorders; generalized anxiety disorder (GAD), panic disorder (PD), and society anxiety disorder (SAD)); See also e.g. National Institute of Health Website, Clinical Pharmacology, http://dailymed.nlm.nih.gov/dailymed/drugInfo.cfm?id=4787\#nlm34090-1 (last visited Oct. 4, 2009) (explaining that the actual mechanism of action of imipramine is not definitively known, but that it is hypothesized to work by blocking the uptake of norepinephrine at nerve endings).

159 "Chick lit" was about the limit for holding my attention during my "gray" periods.

${ }^{160}$ See supra text at notes [].

161 "Supervision" in this context refers to support and feedback from an experienced practitioner with respect to clinical skills, especially those related to personal skills, rather than responsibility for, or control of, the practitioner's work.
} 
That night, months later, while revisiting why I so quickly concluded that it would be impossible, I decided that I would embark on research to explore the feasibility of providing some sort of ongoing supervision or support for attorneys' personal skills, something I ultimately dubbed "PSS," or "Personal Skills Support." ${ }^{162}$ And I did. Not only did I speak and write on the subject, I even commenced a peer support group pilot program at Touro. I also collaborated with the director of the New York City Bar Association's Lawyer Assistance Program ${ }^{163}$ and, a young practicing attorney I tracked down after discovering an article she wrote, ${ }^{164}$ to start up one or more groups in New York City. ${ }^{165}$

It was so wonderful to have an original thought, a potentially creative idea, again! Maybe I hadn't suffered significant cognitive damage after all.

\section{Gratitude}

\section{For a Calling}

In fact, in the four and a half years of wellness I have enjoyed since the waning of the last depressive episode, I have experienced more mental acuity than I can recall having had in years. Sure, there are words that stick on the tip of my tongue-or often much further back. I am, after all, in my seventh decade of life. But I have not had that awful feeling of not being able to construct a cogent English sentence that had plagued me on and off for years before the last episode. I have been more prolific as a writer and speaker than ever before. And while my unorthodox teaching methods certainly don't please all of my students, ${ }^{166}$ I have confidence in the soundness of the choices I

\footnotetext{
${ }^{162}$ Marjorie A. Silver, Supporting Attorneys' Personal Skills, 78 ReVISTA JURIDICA EsCUELA DE DERECHO U. PUERTO RICO 147, 149 (2009).

${ }^{163}$ Eileen Travis, LCSW.

${ }^{164}$ Sofia Yakren, Lawyering as Emotional Labor, 42 UNIV. OF Mich. J. OF L. REFoRM 141(2008).

${ }^{165}$ Unfortunately, these efforts have proven less than successful. But that's another story.

${ }^{166}$ In fact, my first year teaching evaluations, which had previously been solid in the vast majority of categories, have dropped significantly since I transformed the curriculum. I am fairly confident this is due, in large part, to the fact that I am doing something completely different from that to which they are exposed in their other courses. Nonetheless, I continue to try to accommodate their legitimate needs and desires in order to improve my students' learning experiences and wellbeing. Unhappy students do not learn as well as happy students, although I am, nonetheless, convinced that most of my students are learning important lawyering values, skills and knowledge that they are not acquiring elsewhere. I continue to work at
} 
have made and in my reasons for doing so. I continue to be excited by the challenge of finding more effective approaches to educating my students.

And I continue to be blessed with a life filled with meaning, a life in which work and play are almost seamlessly integrated. For some time now, my biggest joy in teaching has not been pondering civil procedure's esoteric applications or interpreting ambiguous doctrine-which was, after all, my focus and passion as a law student, and in the early years of my teaching career-but rather in instilling in my students an appreciation of how critically important it is that they find a life in the law that comports with their core values, a vocation to which they can wake each morning eager to begin the day. It's the main theme of my Civil Externship seminar ${ }^{167}$ and, as time goes on, a theme I integrate throughout my interactions with students, both within and outside the classroom.

\section{For Family, Friends, and Childcare Providers}

Who knows where I would be now had I not had the love and support of family, friends, and colleagues throughout the past three and a half decades? I owe so much to my family, to Doug in particular, for keeping me safe, for believing in me and continuing to love me when I had lost all belief in and love for myself. If J hadn't seen me through my first episode and responded at the commencement of my second, if my parents hadn't been there when J no longer was, if Doug had given up on me during what should have been our time to celebrate our marriage, or on any number of other occasions after that, would I have survived? If I did somehow survive, I don't imagine I would have anywhere close to the precious life I have today.

improving my teaching, seeking outside wisdom and support. See, e.g., Michael Hunter Schwartz, SOPHIE SPARROW \& GERALD HeSS, TEACHING LAW By DESIGN: ENGaging StUdENTS FROM THE

SYlLABUS TO THE FINAL EXAM (2009), which I read this past summer. I tried out many of the suggestions in this excellent book this past year, and while from my perspective it was the most successful first year class I could recall, in terms of student engagement, and my rapport with the class, student evaluations did not reflect that sentiment was widely shared. So even in my seventh decade, my teaching continues to be a work-in-progress, one that I intend never to abandon as long as I am able to teach.

${ }^{167}$ See supra text at note []. 
As others have so powerfully written, depression is, at least for me, a disease of selfimposed social and emotional isolation. ${ }^{168}$ During an episode, I cut myself off from all of my friends. I don't want to answer the phone, or the knock at the door. I am terrified of being left alone, but Doug has generally been the only person I am willing to have near me, and I count on him to negotiate my existence with the rest of the world. ${ }^{169}$ But thankfully, my friends and the other members of my family are out there, eager to help in any way they can. And when I have felt well enough to see them again, their concern, love and support have been critical in helping me believe I could reclaim the life I thought I had lost.

I was so certain that my depressive episodes would scar my children forever. Instead, they have grown into two remarkable, wonderful adults. I am so fortunate that my children had such loving, competent people to care for them when I was unable to do so. The combination of loving fathers, extended family, and wonderful caregivers ${ }^{170}$ ameliorated the effects of my episodic absences, and, I believe, prevented the scarring I so feared. ${ }^{171}$

\section{For my employers and colleagues}

At any of a number of junctures, my career might have fallen off track, but for empathic individuals such as Richard Merrill, Jim Simon and Larry Raful. As I mentioned earlier, Richard Merrill didn't know me at all, and yet he accommodated my needs with such generous compassion. ${ }^{172}$ Deans Simon and Raful too, responded with supportive concern and, by continuing my salary even while I could not teach, removed a significant

\footnotetext{
${ }^{168}$ See,e.g., KARP, at 34-38. [other cites?]

${ }^{169}$ See supra text at notes [].

${ }^{170}$ I am especially grateful to Mrs. Clara Smith, who cared for baby Josh when we lived in Bethesda, and to Lydia Rodriguez, Lucy's babysitter from sixth months on, until Lucy was able to be on her own after school. Josh may not remember Mrs. Smith, but I am confident that Lucy will never forget her "Titi" Lydia.

${ }^{171}$ Of course, it is also relevant that for the vast majority of their lives, I have not been depressed. [need cite]

${ }^{172}$ See supra text at note [].
} 
obstacle to my recovery. And then there were my colleagues who have taken over my courses and other responsibilities when I took leaves; I am so grateful to all of them. ${ }^{173}$

As I write this, I know that chances are high that I will experience one or more breakdowns during the remainder of my years. ${ }^{174}$ Of course I have hope that perhaps, with the knowledge I now have that no medication offers an iron-clad, lifetime guaranty, and that excessive stress threatens to derail my mental equilibrium, ${ }^{175}$ I can avoid any complete breakdown. But the future is uncertain for all of us. All any of us has for sure is now.

\section{Depression's Gifts ${ }^{176}$}

For many, many years, I have been "out of the closet" about my mental health history. ${ }^{177}$ I have shared it when we discuss in Professional Responsibility whether or not attorneys who have been disbarred for transgressions committed due to mental illness should be readmitted upon recovery. ${ }^{178}$ I have counseled students suffering from intense anxiety or depression, and have been able to use my own experience to normalize their experience, and offer hope and guidance. But I decided I wanted and could do more.

\footnotetext{
${ }^{173}$ These include Jethro Lieberman at New York Law School and Fabio Arcila and Lew Silverman at Touro. Lew even graded a set of my Fall '06 final exams. And my dear friend and former colleague, Larry Grosberg offered to grade my exams in 1985, an offer, however, I didn't need to accept.

${ }^{174}$ See supra note [] and accompanying text.

${ }^{175} \mathrm{I}$ know now that it is essential that I not take on more projects and responsibilities than I can comfortably handle, and I have had occasion since the last episode of depression to remind the dean of this when he asked whether I would be willing to take on two first year sections.

${ }^{176}$ Cf. Jonah Lehrer, Depression's Upside, N.Y. TIMES, Feb. 28, 2010, at 38 (discussing [to be filled in]).

${ }^{177}$ Compare this with what James discloses in Walking the Tightrope, supra note [] at 3-5 (describing how he hid his bipolar disorder for fear of stigma and being ostracized).

${ }^{178}$ In addition to the infamous case involving Robert Rowe, see In the Matter of Robert T. Rowe, 80 N.Y.2d 336 (1992), see Julie Solomon, AgAinst THE WIND (xxxx) in Richard Zitrin, et al, we discuss the case involving Touro's own esteemed adjunct professor, Sol Wachtler, former Chief Judge of the New York State Court of Appeals, who relinquished his license upon his conviction for criminal harassment, the circumstances of which were the result of self-medication of a then undiagnosed bipolar disorder. Gregory Pingree, Where Lies the Emperor's Robe? An Inquiry Into the Problem of Judicial Legitimacy, 86 OR. L. ReV. 1095, 1110 (2007); SOl WACHTLER, AFTER THE MADNESS; A JUdGE's Own PRISON MEMOIR 5-7 (1997) (Judge Wachtler explained that his "aberrational conduct" suggested mental illness, but it was not until the prosecutor in his case allowed him to visit a psychiatrist, accompanied by an armed guard and an electronic monitor attached to his ankle, that it was determined that he was suffering from a "drug induced and exacerbated bipolar disorder."). Judge Wachtler was denied readmission in 2003, but ultimately regained his law license in 2007. Disgraced Ex-Chief Judge is Readmitted to Bar, 10/3/2007 N.Y.L.J. 1 (Oct. 3, 2007).
} 
Several years ago, I sought and obtained a position on the board of the New York State Lawyer Assistance Trust, where I chaired the Committee on Law School Outreach. My specific desire was to broaden the Trust's efforts with respect to mental illness. The Trust's mission, as originally conceived by Chief Judge Judith Kaye in 2001, was to provide support to lawyers and programs throughout the state on issues of substance abuse: drug and alcohol addiction and prevention. Through the efforts of many, its mission expanded in 2006 to address mental health as well. ${ }^{179}$ Lawyer Assistance Programs (LAPs) throughout the state have reported that they receive more inquiries from lawyers suffering from depression than from substance abuse. ${ }^{180}$ Yet the membership of many LAPs is composed primarily of those who are in recovery from the latter. When I attended the annual NYS Bar Association LAP retreat in 2008, I had the interesting experience of being a member of a distinct minority (single diagnosis depressives) among an overwhelming number of lawyers who had suffered from alcohol and other drug dependency, some of whom resented the expansion of the LAPs' mission. Rather than finding this discouraging or off-putting, it strengthened my resolve that I had an important role to play. During the course of that weekend, the New York City LAP director asked if I would speak to a young lawyer who had recently suffered a mental health breakdown and share my own experience. She had encouraged him to attend the retreat, and he didn't understand what he was doing there "with all of those drunks." Although I found it awkward to start a conversation with a stranger with whom I had little in common, other than that we were both lawyers and both suffered from some form of mental illness (although he appeared to be in denial about what his problem was), I was able to listen deeply to him. He had no job; he resented that no one wanted to hire him, despite his credentials; his girlfriend had left him. I could at least endeavor to help him distinguish that over which he had no control (couldn't force someone to hire him), and that over which he did (move forward in ways that would make him a desirable prospect for work and romance). I don't know if it was effective,

\footnotetext{
${ }^{179}$ New York Lawyer Assistance Trust, http://www.nylat.org/home.cfm (last visited Oct. 4, 2009). 180 [cite]
} 
but the effort itself felt authentic and constructive. And, after all, in this situation, that's all I could control. ${ }^{181}$

I have also joined forces with Touro's Student Services office to enhance and originate efforts to improve our students' wellbeing. In the spring of 2010, I designed a curriculum, based on Professor Lawrence Krieger's The Hidden Sources of Law School Stress, for stress relief discussion groups for first year students. I trained a corps of handpicked facilitators, both faculty and administrators, on how to facilitate these groups. ${ }^{182}$ These sessions were followed by a mandatory program for all first year students at which we screened Getting Healthy Staying Healthy ${ }^{183}$ and a "LAP panel": a member of the Character and Fitness Committee, a LAP director, and an alumna in recovery. $^{184}$

Since then, we have expanded our wellness efforts at Touro and have created a new program, Students Helping Students (SHS). Modeled, in part, after Lawyers Helping Lawyers programs, the name for many Lawyer Assistance Programs, the purpose is to expand the universe of people to whom students under stress or in distress can turn. We have trained empathic students not only to lead the stress relief discussion groups, but to be alert and available to their peers for problems large and small, and to refer

${ }^{181}$ Sometime thereafter, the NYC LAP director, Eileen Travis, asked if I would speak with a young "big firm" associate who was experiencing his first episode of depression. We spoke by phone only, over the course of a couple of weeks during which his antidepressant medication seemed to "kick in." I'm confident that sharing my own history of and recovery from depression - as well as wisdom gleaned from 27 years as a law professor and three plus years on the Lawyer Assistance Trust-was helpful and reassuring to him. But what I received from my privileged place of being of use was a true gift.

${ }^{182}$ This project is described in the NYS LAT’s e-zine, Wellness@Law School that the Law School Outreach committee initiated (April 2010).

In the two groups that I facilitated myself, I disclosed my own history of depression. Afterwards, two of my students sought me out — one whose mother died in the spring semester; another who suffered from chronic anxiety and depression - and I was able to support each of them through their difficult times.

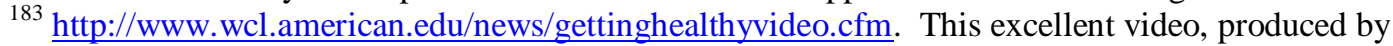
American University's Washington College of Law in 2009, effectively speaks to students about the relationship of drug addiction, alcoholism to obtaining and keeping one's license to practice law, as well as the resources available to law students and lawyers alike through lawyer assistance programs.

${ }^{184}$ In meeting with one of my students on something unrelated a short time after the LAP panel, I sensed that something else was on his mind, and asked him if there was anything he wished to talk about. He said there was, but that he wasn't yet ready to do so. Several weeks later, he asked to meet with me and disclosed that he feared he was at risk of developing a gambling addiction, something from which his father suffered. Thus intervention was possible before any severe problem arose. But for his hearing about and from others who have suffered from addiction, and the help that was available to them, he might never have sought prophylactic assistance. 
students who need services to the appropriate resources, both within and outside of the law school.

And this past term, I took another major step. The Office of Student Affairs and I arranged for two screenings of A Terrible Melancholy, a video about lawyers and law students suffering from depression, created by attorney Dan Lukasik, originator of the website Lawyers With Depression. ${ }^{185}$ Each screening was followed by a panel at which Dan, Andrew Sparkler, vice-president of The David Nee Foundation, ${ }^{186}$ and I shared our stories. It was the first time I had ever shared the details of my depression in a public setting. I spoke about when it first started, what the overwhelming anxiety was like, the zombie state of not feeling love, even for my children, the fear of going outside alone, as my world no longer extended more than two inches in front of my face, and how the depression and anxiety severely compromised my cognitive abilities.

Afterwards, several members of the faculty, staff and student body, some of whom I had known for years, reached out to me, sharing that they had had similar experiences, either themselves or close relatives. Each one expressed so much appreciation that I had spoken publically about something that had been a personal source of substantial shame and secrecy. Thereafter I was invited to be part of a LAP panel and give a similar talk to the entire first year class at CUNY Law School. Several students reached out to personally thank me. I discovered that not only was it not difficult to give these talks; in fact, it felt cathartic. And the gratitude I received in response was priceless.

So I have moved from sharing my own story with my students and others on what might be described as a "micro" basis, to reaching out to the larger legal community. My work on the LAT Board has been a significant platform for such outreach. ${ }^{187}$ But it

\footnotetext{
${ }^{185}$ See www.lawyerswithdepression.com. Dan Lukasik, who suffers from depression, is active in Erie County New York helping other lawyers who suffer.

${ }^{186} \mathrm{See}$ www.daveneefoundation.com. The Dave Nee Foundation was founded as an outreach organization to educate adolescents and young adults about depression and suicide, by classmates of a 2005 Fordham Law School graduate who committed suicide while studying for the bar exam.

${ }^{187}$ I write in the past tense because in the spring of 2011, in response to New York State's budgetary crisis and Governor Cuomo's mandate that the Office of Court Administration (OCA) cut millions from their budget, the Trust was completely defunded. The Board still exists, allegedly in an advisory capacity, and it is hoped that it will be revived when the crisis passes, but its future is unknown.
} 
doesn't end there. I hope this article will reach many more members of the legal community and the academy.

Finally-at least for now-my last episode of depression features in my husband's 2010 personal documentary, The Kids Grow Up. ${ }^{188}$ The film is, at its core, about raising your children just to have them leave you. It is centered on our daughter Lucy's last year at home before she left for college in August 2007. One of the things that happened that year is that I got depressed, and then I got better. By showing that depression, for some of us, is an illness not unlike a number of physical illnesses (cancer, diabetes, heart disease) that with proper treatment can be controlled, I hope it will help de-stigmatize mental illness. I have participated in numerous " $Q \& A$ "s after film festival screenings of The Kids, at which I have the opportunity to talk to large audiences about depression and how it doesn't define me or my life. And that's what they see in a film that is not about depression. I am fine, then I'm depressed, and then I'm fine again. It normalizes depression in a way that few other vehicles are able. I can tell from the positive, grateful, feedback I have received from many audience members that it has had the intended impact. ${ }^{189}$

Two years ago, one of my seminar students emailed me that she had just been rushed to the hospital that Friday morning, suffering from what turned out to be a panic attack. She told her externship supervisor that she wouldn't be into work because of an asthma attack. She also wrote that the hospital had insisted she take Xanax ${ }^{\mathrm{TM}}$, at least over the weekend, and get some psychological help. The latter is something she and I had recently discussed, as a recent ending of a relationship had left her anxious and distracted. She hated taking a mood-altering medication such as Xanax ${ }^{\mathrm{TM}}$. I wrote her back, as follows:

\footnotetext{
${ }^{188}$ The Kids Grow Up (2010). The film is currently available on DVD and as a download (to rent or to buy). See, e.g., http://www.amazon.com/s/ref=nb_sb_ss_c 1_16?url=search-alias\%3Dmovies-tv\&fieldkeywords=the+kids+grow+up\&sprefix $=$ the+kids+grow + up.

${ }^{189}$ I am repeatedly told that I was so brave to allow my depression to appear in the film, or talk about it publically. I respond that it doesn't feel like bravery, because it is part of my calling. That it is viewed as a brave act, I believe, only reinforces how far we have yet to go in destigmatizing depression and other mental illness.
} 
Thanks for letting me know. Any time you want to talk--even over the weekend if you want--I'm here for you .... I'm someone who has benefited greatly from antidepressant medication and, as needed, anti-anxiety medications like Xanax ${ }^{\mathrm{TM}}$. And now I'm involved in efforts to destigmatize mental health problems, so that someday, I hope, revealing that you have had a panic attack won't be any more embarrassing than revealing that you have had an asthma attack. But I know most people aren't there yet!

Her email to me suggested that she had internalized the shame that results from mental illness. I didn't want to say this directly; I hoped what I wrote would help her see what had happened to her from a different perspective. My email won't cure the problem of shame or stigma, nor will depicting my depression in The Kids, but I am thankful every time I have the opportunity to make an effort in that direction. That is why I am letting my depressed-and depressing - persona appear on movie screens all over the world.

Hopefully, by speaking out, by going public, I will inspire others to do the same. I hope my students will have the courage not only to share their stories with me, but as they proceed on the journey that will become their legal careers, they will use their experiences to help clients who are suffering as well. Whether an attorney should share personal details about herself with a client is a sensitive issue, dependent on the attorney, the client, and the circumstances. ${ }^{190}$ When done, however, for the benefit of the client, to improve the client's therapeutic outcome, it constitutes good lawyering. ${ }^{191}$

We who enjoy the privilege and security of being tenured members of the legal academy have the freedom and authority to be powerful voices in removing the stigma of mental illness. Those of us who have suffered ourselves are blessed with the opportunity to be of help to those who otherwise will suffer unnecessarily. How can we not heed that call?

\section{Conclusion}

So, once again I want to thank Elyn Saks and James Jones for their courage in sharing their stories and prompting me to write my own. I feel I am among the lucky ones; not

\footnotetext{
${ }^{190}$ See, e.g.

191 [Cite to David Wexler's new article.]
} 
all readers who suffer from depression will experience the degree of joy, the ability to carpe diem, that I experience so much of the time. As Dan Lukasik once reminded me, many of those who suffer from depression will do little better than manage their illness. The experience of depression differs for each one of us afflicted. But I do believe that many people who suffer from mental illness, with the necessary support of those who care about and for them, can achieve a level of success and satisfaction with their lives far beyond what most of them-and most of society-believe possible. I hope my story here about my experiences with depression will help some readers with their own struggles, and help all readers better understand the struggles of their students, colleagues, clients and loved ones. And I wish to join James Jones, ${ }^{192}$ in welcoming hearing from those to whom I might be of service.

\footnotetext{
${ }^{192}$ See Jones, supra, note [] at 374.
} 